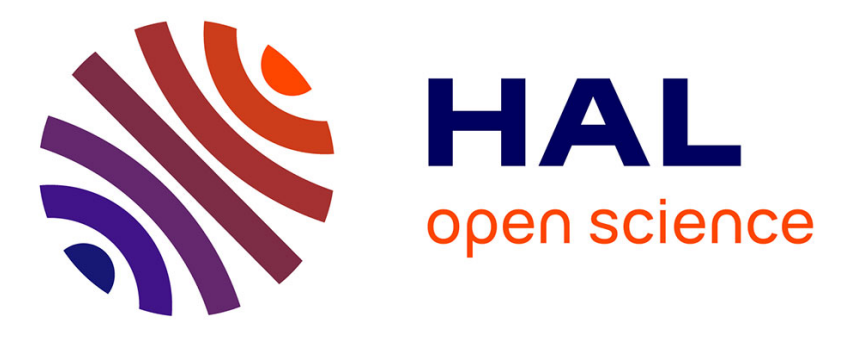

\title{
Interactions of pesticides with membrane drug transporters implications for toxicokinetics and toxicity
}

Lisa Chedik, Arnaud Bruyère, Astrid Bacle, Sophie Potin, Marc Le Vée, Olivier Fardel

\section{- To cite this version:}

Lisa Chedik, Arnaud Bruyère, Astrid Bacle, Sophie Potin, Marc Le Vée, et al.. Interactions of pesticides with membrane drug transporters implications for toxicokinetics and toxicity. Expert Opinion on Drug Metabolism and Toxicology, 2018, 14 (7), pp.739-752. 10.1080/17425255.2018.1487398 . hal-01863032v2

\section{HAL Id: hal-01863032}

\section{https://hal-univ-rennes1.archives-ouvertes.fr/hal-01863032v2}

Submitted on 6 Sep 2018

HAL is a multi-disciplinary open access archive for the deposit and dissemination of scientific research documents, whether they are published or not. The documents may come from teaching and research institutions in France or abroad, or from public or private research centers.
L'archive ouverte pluridisciplinaire $\mathbf{H A L}$, est destinée au dépôt et à la diffusion de documents scientifiques de niveau recherche, publiés ou non, émanant des établissements d'enseignement et de recherche français ou étrangers, des laboratoires publics ou privés. 


\title{
Interactions of pesticides with membrane drug transporters: Implications for toxicokinetics and toxicity
}

\author{
Lisa Chedik ${ }^{1}$, Arnaud Bruyere ${ }^{1}$, Astrid Bacle ${ }^{1,2}$, Sophie Potin ${ }^{1,2}$, Marc Le Vée ${ }^{1}$, Olivier \\ Fardel $^{1,3}$ \\ ${ }^{1}$ Univ Rennes, Inserm, EHESP, Irset (Institut de recherche en santé, environnement et travail) \\ - UMR_S 1085, F-35043 Rennes, France \\ ${ }^{2}$ Pôle Pharmacie, Centre Hospitalier Universitaire, Rennes, France \\ ${ }^{3}$ Pôle Biologie, Centre Hospitalier Universitaire, Rennes, France
}

Address correspondence to: Dr. Olivier Fardel, Institut de Recherches en Santé, Environnement et Travail (IRSET), UMR INSERM U1085, Faculté de Pharmacie, 2 Avenue du Pr Léon Bernard, 34043 Rennes, France. Tel: (33) 2232348 80; Fax: (33) 22349 97; Email: olivier.fardel@univ-rennes1.fr

\section{Funding}

This paper was not funded.

\section{Declaration of interest}

The authors have no relevant affiliations or financial involvement with any organization or entity with a financial interest in or financial conflict with the subject matter or materials discussed in the manuscript. This includes employment, consultancies, honoraria, stock ownership or options, expert testimony, grants or patents received or pending, or royalties.

\section{Reviewer declaration of interest}

Peer reviewers on this manuscript have no relevant financial or other relationships to disclose 


\begin{abstract}
Introduction: Drug transporters are now recognized as major actors of pharmacokinetics. They are also likely implicated in toxicokinetics and toxicology of environmental pollutants, notably pesticides, to which humans are widely exposed and which are known to exert various deleterious effects towards health. Interactions of pesticides with drug transporters are therefore important to consider.
\end{abstract}

Areas covered: This review provides an overview of the interactions of pesticides with membrane drug transporters, i.e., inhibition of their activity, regulation of their expression and handling of pesticides. Consequences for toxicokinetics and toxicity of pesticides are additionally summarized and discussed.

Expert opinion: Some pesticides belonging to several chemical classes, such as organochlorine, pyrethroid and organophosphorus pesticides, have been demonstrated to interact with various uptake and efflux drug transporters, including the efflux pump Pglycoprotein and the uptake organic cation transporters (OCTs). This provides the proof of the concept that pesticide-transporter relationships merit attention. More extensive and systematic characterization of pesticide-transporter relationships, possibly through the use of in silico methods, is however likely required. In addition, consideration of transporter polymorphisms, pesticide mixture effects and realistic pesticide concentrations reached in humans, may help to better define the in vivo relevance of pesticide-transporter interactions in terms of toxicokinetics and toxicity. 
Key-words: Drug transporters; environmental exposure; pesticides; toxicity; toxicokinetics

\section{Article highlights}

- Interactions of organic pesticides with drug transporters are important to consider owing to the major contribution of transporters to toxicokinetics and the well-established toxic effects of pesticides, to which humans are widely exposed.

- Various pesticides belonging to diverse chemical classes, including organochlorines, pyrethroid and organophosphorus pesticides, can inhibit the activity of ATP-binding cassette or solute carrier drug transporters. Activities of the drug efflux pump P-glycoprotein and of the uptake organic cation transporter (OCT) 1 and OCT 2 have notably been demonstrated to be impacted by pesticides.

- Concentrations of pesticides that block in vitro transporter activities (in the 1-100 $\mu \mathrm{M}$ range) are commonly much higher than those reached in humans in response to environmental exposure, making the in vivo relevance of transporter inhibition unlikely for most of pesticides.

- A limited number of pesticides has been shown to regulate expression of some drug transporters, notably in hepatic cells.

- Pesticides can additionally be substrates for drug transporters, which may contribute to their toxicokinetics and may also govern their toxicity.

- Overall, pesticides remain poorly characterized with respect to relationships with transporters. A more extensive and systematic characterization of the interactions of pesticides with drug transporters is consequently required. Polymorphisms in transporters, 
pesticide mixture effects and the interplay between transporters and drug metabolizing enzymes constitute additional issues that warrant attention.

\section{Introduction}

Drug transporters are plasma membrane proteins, implicated in the cellular uptake or efflux of xenobiotics. They belong to the solute carrier (SLC) or ATP binding cassette (ABC) transporter superfamilies [1]. Human SLC transporters are usually implicated in the uptake of drugs, through mediating facilitated diffusion or secondary active transport across the plasma membrane [2], whereas $\mathrm{ABC}$ transporters are efflux pumps, responsible for the primary active export of drugs out of cells, through their intrinsic ATPase activity [3]. Both SLC and ABC transporters are expressed at anatomical/histological sites important for xenobiotic disposition, including intestine, blood-tissue barriers like the blood-brain barrier, liver and kidney [4]. By this way, drug transporters play a major role in the different steps of pharmacokinetics, including absorption, distribution and hepatic and renal elimination $[5,6]$. They may consequently influence drug efficacy as well as drug toxicity. Moreover, drugmediated inhibition of their activity can cause pharmacokinetic-based drug-drug interactions [7]. This has led drug regulatory agencies to edict guidances for the study of putative interactions of new molecular entities with clinically-relevant drug transporters [8].

In addition to drugs, environmental pollutants can interact with transporters, i.e., they inhibit and/or are handled by them $[9,10,11]$, which may have consequences in terms of the toxicokinetics and toxicity of pollutants. Environmental chemicals may additionally regulate levels of transporter expression, i.e., they notably enhance transporter expression, which may in turn result in increased transport activity [12]. Among pollutants which have to be 
considered for putative interactions with drug transporter activity and/or expression, chemical organic pesticides are likely major ones. Indeed, these compounds, defined as any chemical or mixture of chemical intended for preventing, destroying, repelling, or mitigating pests, and belonging to diverse chemical classes (See Table 1 for a schematic presentation of main classes of organic pesticides), are largely used for occupational (agriculture...) or domestic purposes, for notably their insecticide, herbicide, fungicide or rodenticide properties. They are consequently widely distributed in the environment and humans can be exposed to them in a major way, through the oral, dermal or pulmonary route. Such exposures are thought to promote the development of various pathologies, including cancers, neurologic diseases and endocrine disruption, owing to the diverse toxic effects of pesticides $[13,14]$. In the present review, we have summarized the current knowledges about interactions of human drug transporters with organic pesticides, with special emphasis on possible consequences in terms of pesticide toxicokinetics and toxicity.

\section{Interactions of pesticides with $\mathrm{ABC}$ transporter activities}

\subsection{Interactions with P-glycoprotein $(P$-gp) activity}

P-gp, encoded by multidrug resistance gene $1(M D R 1 / A B C B 1)$, was historically characterized as an efflux pump for various structurally-unrelated anticancer drugs [15], thus conferring multidrug resistance to cancer cells (See Table 2 for a summary of main drug transporters). Pgp also handles many non-anticancer drugs like the cardiotonic drug digoxin. It is physiologically expressed at various blood-tissue barriers and in absorptive or excretory organs such as the gut, the liver and the kidney; by this way, P-gp plays a major role in pharmacokinetics [16].

Various pesticides, belonging to diverse classes, have been shown to inhibit human Pgp activity. This has been mainly demonstrated through analyzing their effects on cellular 
accumulation or efflux of radiolabeled or fluorescent reference P-gp substrates in P-gp expressing cells $[17,18]$. The threshold of at least $50 \%$ inhibition of P-gp activity by pesticides used at $100 \mu \mathrm{M}$ or $250 \mu \mathrm{M}$ concentration can be retained for considering a pesticide as a P-gp inhibitor. Using this criteria, the organochlorine insecticides chlordecone, heptachlor and heptachlor epoxide, the organophosphate insecticides azinphos-ethyl, chlorpyrifos, coumaphos, phosalone, chlorthiophos, dicapthon, parathion, diazinon and fenamiphos, the avermectins ivermectin, abamectin and emamectin benzoate and the fungicide clotrimazole have been identified as inhibitors of human P-gp [12, 17, 19, 20, 21, $22,23,24]$. Tetrachlorohydroquinone, a major metabolite of pentachlorophenol, as well as the insecticide hydramethylnon and the fungicide propiconazole and its metabolites, also block Pgp-mediated transport $[17,25]$. The dibenzoylhydrazines tebufenozide and methoxyfenozide, which exert their insecticide activity through permanent activation of the ecdysone receptor, constitute additional P-gp inhibitors; they decrease P-gp-mediated transport of the antiarrhythmic agent quinidine [26]. With respect to endosulfan, it was found to inhibit human P-gp in three studies $[17,21,27]$, but not in two other studies $[12,20]$, which may reflect differences in the various P-gp activity assays used in these studies. The herbicides acetochlor, alachlor, metolachlor and metazachlor, unlike dimetachlor, propachlor and prynachlor, have also been described as P-gp inhibitors [28]. Half maximal inhibitory concentrations $\left(\mathrm{IC}_{50}\right)$ are available only for a few pesticides inhibiting P-gp. In the study of Bain and al. [19], they range from $7.3 \mu \mathrm{M}$ (hydramethylnon) to $229.8 \mu \mathrm{M}$ (parathion). $\mathrm{IC}_{50}$ values for P-gp inhibition by endosulfan, phosalone and propiconazole are however lower, i.e., around $3 \mu \mathrm{M}$ [21]; similarly, avermectins block P-gp-mediated efflux at low concentrations, around 0.2-0.6 $\mu \mathrm{M}[24]$. Other pesticides such as the carbamates aldicarb, aldoxycarb, aminocarb, carbaryl and propoxur, the dithiocarbamate maneb, the organophosphate pesticides mevinphos, dialifos and phosmet, the phenoxy herbicide 
fluazifop-butyl and various pyrethroids (allethrin, bifenthrin, $\beta$-cyfluthrin, $\lambda$-cyhalothrin, $\beta$ cypermethrin, deltamethrin, esfenvalerate, fenpropathrin, fluvalinate, cis-permethrin, transpermethrin, resmethrin, tefluthrin and tetramethrin), failed to inhibit human P-gp activity to a significant extent $[12,17,18,19]$. It was also the case for atrazine, paraquat, propiconazole, vinclozolin and the organochlorine insecticides 2,4 '- dichlorodiphenyltrichloroethane (DDT), chlordane and toxaphene $[12,17]$, as well as for cyperquat [29], a bipyridil compound also known as 1-methyl-4-phenylpyridinium (MPP+), which has been used as an herbicide in the past. Additional organochlorine pesticides such as 4,4'-DDT, dieldrin, lindane, methoxychlor and mirex did not block human P-gp-mediated transport [17], whereas they inhibited that of mouse P-gp [11], suggesting inter-species differences with respect to interaction of P-gp with pesticides. 2,4'-DDT and 4,4'-DDT as well as their metabolite dichlorodiphenyldichloroethane (DDE) nevertheless decreased human P-gp ATPase activity [30]. For major classes of pesticides, the relative percentage of chemicals inhibiting drug transporters, including P-gp, as well as the total number of compound tested against transporter activity, according to published data, are indicated in Table 3.

Transport of pesticides by human P-gp has been investigated through direct analysis of their cellular accumulation or efflux in P-gp-positive cells, and also by measuring the stimulation/modulation of P-gp ATPase activity, which constitutes an indirect argument for Pgp-mediated transport. According to experimental data, there is only limited evidence for pesticides as substrates for the efflux pump (See Table 4 for a summary of pesticides handled by drug transporters). P-gp has been demonstrated to handle paraquat and thus protects against cytotoxicity induced by this pesticide $[31,32,33,34,35]$, but may fail to contribute to the systemic pharmacokinetics of this herbicide in mice [36]. The avermectins ivermectin and selamectin are substrates for P-gp [37, 38], notably in mouse where the pump limits the brain penetration of ivermectin [39]. Endosulfan may be a weak substrate for P-gp [17]. The 
organophosphate pesticide diazinon as well as rotenone have also been suggested to be P-gp substrates, because they stimulated P-gp ATPase activity, unlike dieldrin, endosulfan, ivermectin and maneb, without however inhibiting P-gp-mediated transport of rhodamine 123 [20]. Dibenzoylhydrazine insecticides stimulated P-gp ATPase activity, but are in fact poorly transported by the pump [26]. P-gp ATPase activity is additionally stimulated by methylparathion, cypermethrin and fenvalerate [27], whereas P-gp seems to be not involved in resistance of intestinal Caco-2 cells to propoxur, thus likely discarding the hypothesis that the carbamate may be transported by the pump [40]. Propiconazole was also not handled by P-gp [25], as well as deltamethrin, cis-permethrin and trans-permethrin [41], the rodenticide anti-vitamin K warfarin [42] or the herbicide cyperquat/MPP+ [29, 43, 44].

\subsection{Interactions with multidrug resistance-associated protein (MRP/ABCC) activities}

MRPs constitute a group of $\mathrm{ABC}$ transporters, comprising nine members in humans. Seven of these nine MRPs, i.e., MRP1 (ABCC1), MRP2 (ABCC2), MRP3 (ABCC3), MRP4 (ABCC4), MRP5 (ABCC5), MRP7 (ABCC10) and MRP8 (ABCC11), have been unambiguously demonstrated to transport drugs, especially anionic drugs [45]. MRP1 was historically the first identified MRP; it was initially characterized as an efflux transporter for anticancer drugs overexpressed in drug-resistant cancer cells. MRP1 was next demonstrated to exhibit a broad tissue distribution and to transport a wide range of xenobiotics, including anionic drugs and drug conjugates [46]. MRP2, like MRP1, primarily transports organic anions and is expressed in various tissues, especially in the liver, kidney and gastrointestinal tract [47]. MRP3 is present in several tissues, including the liver, where it is located at the sinusoidal pole of hepatocytes; it notably transports xenobiotics from the liver into the blood, for a secondary

renal elimination. MRP4 is notably expressed in the kidney and the liver and at the bloodbrain barrier. It has wide substrate specificity, including nucleoside analogues and antiviral drugs. MRP5 is almost ubiquitously expressed in human tissues. It effluxes a broad range of 
natural and xenobiotic compounds such as cyclic GMP, antiviral compounds and cancer chemotherapeutic agents. MRP7 confers anticancer drug resistance [48], as well as MRP8, notably towards nucleoside analogs [49],

The avermectins abamectin, emamectin and ivermectin have been reported to inhibit MRP activity; the corresponding $\mathrm{IC}_{50}$ values are around 1.5-2.0 $\mu \mathrm{M}$ and have been determined through measuring MRP-mediated efflux of the dye glutathione methylfluorescein in human neuronal SH-SY5Y cells [24]. The fact that ivermectin inhibited MRP1, MRP2 and MRP3 ATPase activities after stimulation by their respective activators [38] fully supports this conclusion. Whether ivermectin may be a good substrate for MRP1 remains however to be established, because conflicting data about this point have been reported [37, 38]. The pyrethroids allethrin and tetramethrin, unlike bifenthrin, $\beta$-cyfluthrin, $\lambda$-cyhalothrin, $\beta$ cypermethrin, deltamethrin, esfenvalerate, fenpropathrin, fluvalinate, cis-permethrin, transpermethrin, resmethrin and tefluthrin, were found to inhibit MRP activity in hepatoma MRP2expressing $\mathrm{HuH}-7$ cells, with $\mathrm{IC}_{50}$ values around 40-50 $\mu \mathrm{M}$ [18]. The organochlorine pesticides endosulfan, chlordane, heptachlor and chordecone also blocked MRP-mediated efflux in HuH-7 cells, whereas 4,4'-DDT, 2,4'-DDT, dieldrin and lindane were without effect [12]. None of the chloroacetanilides acetochlor, alachlor, dimetachlor, metazachlor, metolachlor, propachlor and prynachlor interacts with MRP1 or MRP2; MRP1 was however demonstrated to transport an important intermediate of the acetochlor detoxification pathway [28]. MRP1 additionally handles the chloroacetanilide herbicide methoxychlor and confers resistance to the organophosphorus insecticide fenitrothion and the carbamate herbicide chlorpropham, suggesting that these two pesticides may also be substrates [50].

\subsection{Interactions with breast cancer resistance protein (BCRP/ABCG2) activity}

$\mathrm{BCRP}$ is an $\mathrm{ABC}$ transporter handling both anticancer drugs and non-anticancer drugs, like statins, as well as environmental chemicals like carcinogenic heterocyclic aromatic amines 
[51] and endogenous compounds like urate [52]. It is expressed at blood-tissue barriers and in gut and excretory organs like liver and kidney. BCRP is also present in stem cells.

The organochlorine pesticides endosulfan, chlordane, heptachlor and chordecone inhibit BCRP efflux activity, whereas 4,4'-DDT, 2,4'-DDT, dieldrin and lindane are without effect [12]; 2,4'-DDT and 4,4'-DDT as well as their metabolite dichlorodiphenyldichloroethane (DDE) have nevertheless been reported to inhibit human BCRP ATPase activity [30]. The pyrethroids allethrin and tetramethrin, unlike bifenthrin, $\beta$ cyfluthrin, $\lambda$-cyhalothrin, $\beta$-cypermethrin, deltamethrin, esfenvalerate, fenpropathrin, fluvalinate, cis-permethrin, trans-permethrin, resmethrin and tefluthrin, have been found to inhibit BCRP activity, i.e., BCRP-mediated efflux of the fluorescent dye Hoechst 33342, with $\mathrm{IC}_{50}$ values around 40-70 $\mu \mathrm{M}[18]$. The Hoechst $\mathrm{H} 33342$ accumulation assay also indicated that thirteen widely-used pesticidal active substances including the fungicides azoxystrobin, dimethomorph, dithianon and tolclofos-methyl, the benzidizamole carbendazim, the organophosphate pesticides chlorpyrifos and dimethoate, the herbicides chlormequat, diflufenican and ioxynil, the carbamates methiocarb and propamocarb and the sulfonylurea herbicide rimsulfuron are likely inhibitor of rabbit BCRP; no such evidence was obtained for chlorpyrifos-methyl, epoxiconazole, imazalil (also known as enilconazole), glyphosate and thiacloprid [53]. BCRP was additionally found to transport the rodenticide warfarin [54], whereas ivermectin is unlikely to be a substrate for the pump [55], even if it inhibits its activity, with a rather low $\mathrm{IC}_{50}$ value $(2.2 \mu \mathrm{M})[56]$.

\section{Interactions of pesticides with SLC drug transporter activities}

\subsection{Interactions with activity of SLC drug transporters handling organic cations}

SLC drug transporters transporting organic cations mainly correspond to organic cation transporter (OCT) 1 (SLC22A1), OCT2 (SLC22A2) and OCT3 (SLC22A3), acting as 
electrogenic and membrane potential-sensitive diffusional transporters, and to multidrug and toxin extrusion (MATE) protein 1 (SLC47A1) and MATE2-K (SLC47A2) (a functionally active isoform of MATE2), acting as electroneutral, sodium-independent and pH-dependent proton antiporters [57]. OCT1 and MATE1 are located at the sinusoidal and canalicular poles of hepatocytes, respectively, whereas OCT2 and MATE2-K are found at the basolateral and apical membranes of renal proximal tubular cells, respectively. OCT3 has a wide tissue distribution. OCT1, OCT2, MATE1 and MATE2-K handle cationic drugs, including metformin and oxaliplatin [58]. Endogenous compounds such as neurotransmitters are also transported by OCTs.

With a threshold of at least $50 \%$ inhibition of transport activity when used at $100 \mu \mathrm{M}$ for being considered as a transporter inhibitor, the organochlorine pesticides endosulfan, chlordane, heptachlor, dieldrin and lindane, unlike 2-4'-DDT, 4'-DDT and chlordecone, were found to inhibit OCT1 activity in human hepatoma HepaRG cells, with $\mathrm{IC}_{50}$ values of $0.9 \mu \mathrm{M}$ (dieldrin) and $1.5 \mu \mathrm{M}$ (lindane) [12]. The pyrethroids allethrin, imiprothrin, prallethrin and tetramethrin and the organophosphorus pesticides fenamiphos, fenitrothion, malathion, methyl parathion, parathion, phosmet, profenofos and propetamphos also blocked OCT1 activity, as well as that of OCT2, in HEK293 cells overexpressing these transporters [59]; MATE1 activity was similarly inhibited by allethrin, tetramethrin, fenamiphos, phosmet and propetamphos $[18,59]$. By contrast, bifenthrin, $\beta$-cyfluthrin, $\lambda$-cyhalothrin, $\beta$-cypermethrin, deltamethrin, esfenvalerate, fenpropathrin, fluvalinate, cis-permethrin, trans-permethrin, resmethrin and tefluthrin failed to impair activities of OCT1, OCT2 and MATE1. Phenothrin also did not interfere with OCT1 and OCT2 activities. None of pyrethoids or organophosphorus pesticides impair MATE2-K activity $[18,59]$. Allethrin and tetramethrin $\mathrm{IC}_{50}$ values towards OCT1 activity, i.e., OCT1-mediated uptake of the OCT1 reference substrate 4',6-diamidino-2-phenylindole (DAPI), were around $2.6 \mu \mathrm{M}$ and $4.9 \mu \mathrm{M}$, 
respectively. These two pyrethroids, which also blocked OCT1-mediated uptake of the endogenous substrate dopamine, however failed to trans-stimulate OCT1 activity, indicating that they are unlikely to be substrates for OCT1 [18] (Table 4). Analysis of accumulation of these two pesticides into control (MOCK) HEK293 cells and OCT1-transduced HEK293 cells by liquid chromatography tandem-mass spectrometry (LC-MS/MS) fully supports this conclusion, through indicating similar levels of pesticides in control HEK293-MOCK cells and OCT1-positive counterparts (Fig. 1A). Allethrin and tetramethrin also similarly accumulated in MOCK- and OCT2-transduced HEK293 cells (Fig. 1A), thus discarding a transport of these two pesticides by OCT2. By contrast, OCT1-transduced cells displayed increased accumulation of the OCT1 reference substrate DAPI when compared to control MOCK-transduced HEK293 cells (Fig. 1B); in the same way, OCT2-transduced cells exhibited increased accumulation of the OCT2 reference substrate rhodamine 123 (Fig. 1B). Moreover, the OCT1 inhibitor verapamil failed to enhance allethrin and tetramethrin accumulation in OCT1-transduced HEK293 cells, whereas it markedly increased that of DAPI (Fig. 1). The OCT2 inhibitor amitriptyline also enhanced cellular level of rhodamine 123 in OCT2-transduced HEK293 cells, but not those of allethrin and tetramethrin (Fig. 1). Like allethrin and tetramethrin, fenamiphos and phosmet are not transported by OCT1 or OCT2 (Table 4) [59]. By contrast, cyperquat/MPP+ has been demonstrated to be transported by human OCT1, OCT2, OCT3, MATE1 and MATE2-K [60, 61, 62, 63]. MPP+ concomitantly inhibits the transport of the mutagenic vital dye ethidium by OCT1 and OCT2 [64]. OCT2 and MATE1, unlike OCT1 and OCT3, handle paraquat under its native N,N'-dimethyl-4,4'bipyridinium dichloride form, which harbors two cationic charges [65]. The monocationic radical form of $\mathrm{PQ}$, coming from redox cycling with cellular diaphorases such as NADPH oxidase and nitric oxide synthase, has nevertheless been shown to be a substrate for mouse Oct3 [66]. 


\subsection{Interactions with activity of SLC drug transporters handling organic anions}

There are two main families of SLC drug transporters handling organic anions. The first one corresponds to organic anion transporting polypeptides (OATPs/SLCOs), notably OATP1B1 (SLCO1B1), OATP1B3 (SLCO1B3) and OATP2B1 (SLCO2B1) [67]; the second one is that of organic anion transporters (OATs), comprizing OAT1 (SLC22A6) and OAT3 (SLC22A8) [68]. OATP1B1 and OATP1B3 are specifically located at the sinusoidal pole of hepatocytes; OAT1 and OAT3 are present at the basolateral pole of proximal tubular cells, whereas OATP2B1 is more widely distributed. Substrates for OATPs include anionic drugs and endogenous compounds, such as bile acids, bilirubin, prostaglandins and hormones, like thyroxine and steroid conjugates [69]. OATs transport anionic compounds, including drugs such as penicillins and cephalosporins, endogenous compounds such as estrone-3-sulfate and environmental contaminants such as perfluorooctanoic acid [70].

The herbicide 2,4-dichlorophenoxyacetic acid (2,4-D) is a common substrate for human renal OAT1 and OAT3, but its transport by OAT1 is markedly greater than that by OAT3 [71]. The organochlorine pesticides endosulfan, chlordane, heptachlor, dieldrin, lindane, 2-4'-DDT, 4-4'-DDT and chlordecone failed to inhibit OATP activity in human hepatoma HepaRG cells [12]. With respect to pyrethroids, allethrin and tetramethrin inhibited OATP1B1 and OAT3 activities, and cis-stimulated that of OATP2B1 [18]. Similarly, imiprothrin and prallethrin, unlike phenothrin, cis-stimulated OATP2B1 activity and inhibited that of OAT3. By contrast allethrin and tetramethrin failed to alter in a major way activities of OATP1B3 and OAT1. Similarly, bifenthrin, $\beta$-cyfluthrin, $\lambda$-cyhalothrin, $\beta$-cypermethrin, deltamethrin, esfenvalerate, fenpropathrin, fluvalinate, cis-permethrin, trans-permethrin, resmethrin and tefluthrin did not impair OATP1B3 and OAT1 activities, as well as those of OATP1B1, OATP2B1 and OAT3 [18]. Regarding organophosphorus pesticides, OAT3 activity was inhibited by fenamiphos, malathion and profenofos, but cis-stimulated by 
metasystox, whereas dichlorvos, fenitrothion, methamidophos, methyl parathion, monocrotophos, parathion, phosmet, propetamphos and temephos were without effect [59]. No organophosphorus pesticide blocked OAT1. Activity of OATP1B1 was inhibited by profenofos and temephos, whereas that of OATP2B1 was cis-stimulated by fenamiphos, malathion, parathion, phosmet and profenofos [59].

\section{Regulation of drug transporter expression by pesticides}

Pesticides have previously been shown to regulate expression of drug detoxifying proteins such as hepatic cytochromes P-450 (CYPs) $[72,73]$. Indeed, pesticides are known activators of nuclear receptors like pregnane $\mathrm{X}$ receptor $(\mathrm{PXR})$ and constitutive androstane receptor (CAR) [74], acting as xenobiotic-sensing receptors regulating expression of CYPs. By this way, several pesticides among organophosphate chemicals, pyrethroids, carbamates, organochlorines insecticides and phenylurea compounds up-regulated CYP3A4 and CYP2B6 expression in hepatocytes [73]. Drug transporters are also targets for nuclear receptors in human and/or rodent cells [75]. Indeed, PXR activation induces expression of P-gp in intestinal cells [76]. It also enhances levels of MRP2 in primary human hepatocytes [77], MRP3 in human hepatoma HuH-7 cells [78], Bcrp in mouse Sertoli cells [79] and OCT1 in chronic myeloid leukemia cells [80]. CAR additionally up-regulates P-gp in CAR-transfected hepatoma HepG2 cells [81] and intestinal LS174 cells [82]. CAR is also implicated in regulation of MRP2 in primary human hepatocytes [77], Bcrp in mouse and rat brain capillaries [83] and Mrp4 in mouse liver [84]. Another nuclear receptor, i.e., the farnesoid X receptor (FXR), increases hepatic expression of MRP2 [77] and of bile salt export pump (BSEP/ABCB 11) [85], a canalicular hepatic transporter involved in biliary acid elimination.

Pesticides activating drug sensing receptors are consequently susceptible to induce expression of drug transporters. In agreement with this hypothesis, the organochlorine 
insecticides chlordane, heptachlor, dieldrin, lindane, 2,4'-DDT and chlordecone, which are known agonists of PXR [86], increased mRNA expression of P-gp, MRP2 and BCRP in hepatic HepaRG cells when used at $10 \mu \mathrm{M}$ [12]. In the same way, chlorpyrifos, which notably activates PXR and CAR [86, 87], enhanced expression of P-gp and BCRP in human villous cytotrophoblast cells when used at concentration $10-100 \mu \mathrm{M}$ [88]. The exact role played by PXR and/or CAR in this $\mathrm{ABC}$ transporter up-regulation in placental cells remains however unclear because the expression of PXR and CAR is very low in the human placenta [89].PXR and CAR also contribute to the impact of fipronil on hepatic expression of transporters like MRP2 and MRP3 [90]. Nuclear receptors are additionally likely to participate to regulation of transporters (P-gp, BSEP, BCRP or OATP1B1) in primary human hepatocytes exposed to chemicals from the ToxCast320 chemical library, comprising many pesticide active ingredients [91]. Nuclear-receptor independent ways of drug transporter regulation by pesticides have also been described. Thus, ivermectin induced P-gp expression through mRNA stabilization in murine hepatocyte cell line [92]. The sinusoidal sodium-taurocholate cotransporting polypeptide (NTCP/SLC10A1), which is not known to be regulated by PXR or CAR, exhibited decreased mRNA expression in human hepatoma HepaRG cells exposed to organochlorines [12]. Finally, it is noteworthy that transporter induction may result from chronic exposure to pesticides. Thus, P-gp levels are increased in response to repeated exposure of intestinal Caco-2 cells to the organophosphophorus pesticide diazinon [93].

\section{Pesticides as modulators of drug transporter activity or expression: implications for pesticide toxicity}

\subsection{Toxicity due to transporter activity inhibition by pesticides}

Inhibition of $\mathrm{ABC}$ or SLC drug transporter activities by a chemical (called the perpetrator) is susceptible to cause alterations of pharmacokinetics of a drug (called the victim) substrate for 
the incriminated transporter, finally leading to drug toxicity (in the case of increased drug plasma concentration) or drug inefficacy (in the case of decreased drug plasma concentration). In addition, transport of endogenous substrates may be impaired, which may lead to toxicity, like cholestasis due to inhibition of the bile salt transporter BSEP [94], or endocrine disruption linked to altered elimination of hormones. For such effects, a key point to take into account is whether the perpetrator, whose inhibitory effects towards transporter activity are commonly initially demonstrated in in vitro assays, reaches in vivo concentrations efficient against the considered transporter. When the perpetrator is a drug, its in vitro $\mathrm{IC}_{50}$ value has to be confronted to its maximum unbound plasma concentration $\left(\mathrm{I}_{1}\right)$ and to its maximal theoretical gastrointestinal concentration $\left(\mathrm{I}_{2}\right)$, calculated as the oral dose in a volume of 250 $\mathrm{mL}$; according to 2012 FDA guidance for drug-drug interactions, transporter inhibition may be clinically achievable when $\mathrm{I}_{1} / \mathrm{IC}_{50} \geq 0.1$ and/or $\mathrm{I}_{2} / \mathrm{IC}_{50} \geq 10$ [95]. The application of such thresholds for pesticides may indicate that in vivo inhibition of drug transporter activity in response to environmental exposure to pesticides is very unlikely for most of them. Indeed, in vitro $\mathrm{IC}_{50}$ values of pesticides inhibiting transporter activity are usually in the $1-100 \mu \mathrm{M}$ range (see above), whereas their plasma concentrations are often in the 1-100 $\mathrm{nM}$ range in humans $[96,97,98]$. The pesticide concentration may be even much lower when considering only the unbound free ones. This hypothesis is fully supported by the fact that at least some pesticides, such as dieldrin and atrazine, bind extensively to plasma proteins [99, 100]. Average oral daily intake of a pesticide in the food is additionally usually low, in the $\mu \mathrm{g}$ or ng range, making unlikely the fact that pesticide $\mathrm{IC}_{50}$ values against transporter activity may be reached in the gastrointestinal tract. Pesticide-drug interactions as well as inhibition of physiological substrate transport by pesticides may consequently be discarded, for most of pesticides found in the environment. It is however noteworthy that humans are often exposed to mixtures of pesticides or to pesticides and other environmental contaminants, whose inhibitory effects 
towards transporters may be additive or synergic. This may result in in vivo inhibition of transporters in response to exposure to chemical mixtures, even if concentration of each single pesticide of the mixture is low. The fact that binary mixtures of pesticides, including diazinon, have been shown to exhibit synergistic inhibition of P-gp [21] likely supports this hypothesis. It is also noteworthy that pesticide metabolites may cause transporter inhibition. This may be hypothesized to add or synergize with transporter inhibition triggered by the parental pesticide. Examples of pesticide metabolites acting against transporters correspond to hydroxylated metabolites of propiconazole, active against P-gp [25], and to chlorpyrifos oxon, which inhibits drug labelling of P-gp and stimulates its ATPase activity, in contrast to parental chlorpyrifos [101].

\subsection{Toxicity due to transporter expression changes caused by pesticides}

Regulation of drug transporter expression by pesticides, i.e., induction or repression, can theoretically result in enhanced or decreased transport of drugs or endogenous substrates, which may in turn alter pharmacokinetics and/or toxicity. One key point to consider is that environmental exposure to pesticides has to result in in vivo pesticide level sufficient for triggering transporter regulation, which may be unlikely owing to the relative low concentrations of pesticides reported in humans exposed to these chemicals, as already discussed above. Moreover, it is noteworthy that whether transporter expression modulation may result in clinically-significant alteration of drug transporter activity remains to be formally established. In fact most, if not all, clinical drug-drug interactions in relation with transporters are linked to transporter activity inhibition by the drug perpetrator, and not to altered transporter expression [7, 102]. The only example is perhaps that of therapeutic proteins like tocilizumab, a humanized monoclonal antibody against the interleukin-6 receptor. Tocilizumab is thought to restore normal expression of transporters, including P-gp, 
repressed by IL-6 in inflammatory patients, which may be the source of drug-drug interactions [103].

\section{Pesticides as substrates of drug transporters: implications for toxicokinetics and toxicity of pesticides}

\subsection{Implications for toxicokinetics}

Handling of pesticides by ABC and/or SLC transporters is likely to contribute to the different steps of the disposition process, i.e., intestinal absorption, drug disposition, notably across the blood-tissue barriers like the blood-brain barrier, and hepatic and renal elimination. Owing to the well-established drug transporter-drug metabolizing enzymes interplay [104], it may also influence pesticide metabolism. In this context, it is noteworthy that some pesticides such as organochlorine insecticides have historically been considered as lipophilic chemicals, which freely diffuses across the plasma membrane according to their concentration gradient, thus ruling out any major role for drug transporters. This assertion may now be questioned by the putative handling of some pesticides by $\mathrm{ABC}$ transporters, notably P-gp and BCRP. Indeed, these $\mathrm{ABC}$ transporters are present at the apical pole of intestinal cells, where they actively expel their substrates into the digestive lumen, thus preventing their absorption [105]. Handling of lipophilic pesticides by ABC transporters like P-gp and BCRP may therefore theoretically limits their intestinal absorption. Moreover, the concentration of pesticides in the gastrointestinal lumen is believed to be low, as already discussed above, which precludes any saturation of the ABC efflux pumps. Such lipophilic pesticides may therefore behave as class 2 compounds in the biopharmaceutics drug disposition classification system (BDDCS) [106].

Class 2 drugs are highly permeable, so they will generally be able to enter enterocytes by passive diffusion, unaided by uptake transporters. However, due to low solubility limiting luminal concentration, they are unlikely to saturate efflux transporters. Consequently, class 2 
compounds can be pumped out of enterocytes, which can influence bioavailability and absorption rate. Pesticides exhibit limited luminal concentration, like class 2 drugs, even if this probably reflects the low dairy intake of pesticides, and not a poor solubility, as for class 2 drugs. Transport of pesticides by ABC pumps may additionally be implicated in reduced brain penetration of pesticides, through P-gp- and BCRP-mediated efflux into the lumen of brain capillary. The fact that silencing of P-gp led to a 100 -fold increase of ivermectin distribution into the central nervous system of transgenic mice fully supports this assertion [39].

\subsection{Implications for toxicity}

Handling of pesticides by transporters may decrease or increase their toxicity, depending on the nature of transport. Thus, efflux by ABC transporters out of cells is expected to result in reduced intracellular accumulation of pesticides, and by this way, in decreased toxic effects. This is illustrated by the fact that P-gp expression confers resistance to paraquat, through stimulating its cellular export out of cells [32]. By this mechanism, P-gp notably protects against paraquat-induced toxicity in human and mouse proximal tubule cells [31]. Interestingly, the $\mathrm{ABC}$ transporter MRP1 may also confer resistance to paraquat; this may be due to inhibition of apoptosis caused by the pesticide [107]. MRP1 also decreased toxicity of fenitrothion, chlorpropham and methoxychlor in MRP1-transfected cells and protects seminiferous tubules from methoxychlor-induced damage [50]. Overexpression of $\mathrm{ABC}$ transporters has similarly been shown to confer resistance to pesticides in insect cells [108]. Transport of pesticides by $\mathrm{ABC}$ transporters at blood-tissue barriers, notably at the bloodbrain barrier, also contributes to protect these tissues, notably the central nervous system, from pesticide toxicity, as already demonstrated for P-gp and neurologic toxicity of ivermectin [39]. In the same way, P-gp may play the same protective role towards pesticides at the placental barrier. 
Handling of pesticides by drug transporters such as SLC transporters may also result in decreased toxicity of pesticides. Thus, mouse Oct3 mediates cellular entry of paraquat, but only under its reduced monovalent cation form [66]. Because Oct3 is mainly expressed by non-dopaminergic cells in the nigrostriatal region, this Oct3-mediated transport of paraquat contributes to reduce its accumulation in dopaminergic neurons; this highlights a buffering capacity by non-dopaminergic cells, which indirectly protects dopaminergic neurons from toxicity of paraquat [66]. Whether SLC transporters may, by contrast, favor toxicity of pesticides through increasing their intracellular accumulation remains yet unknown. Such a toxicity caused by SLC-transporter mediated uptake of chemicals has nevertheless already been demonstrated for other environmental contaminants such as the microcystin congeners. These compounds, produced by cyanobacteria, use OATP1B1 and OATP1B3 to enter into cells and, therefore, specifically target OATP1B1- or OATP1B3-expressing cells [109]. Such an OATP-mediated uptake is consequently responsible for the selective hepatic toxicity of microcystins [110].

\section{Conclusion}

Various reports have indicated that pesticides belonging to diverse pharmacological/chemical classes can interact with drug transporters. Most of these studies described inhibition of $\mathrm{ABC}$ or SLC drug transporter activities by pesticides; only a few of them concerns the handling of pesticides by transporters or the regulation of transporter expression by pesticides. Importantly, most, if not all, pesticides required concentrations in the $\mu \mathrm{M}$ range for inhibiting transporter activities; such concentrations are much higher than pesticide concentrations (in the $\mathrm{nM}$ range or less) commonly observed in humans exposed to environmental pesticides. Pesticides are therefore unlikely to cause pesticide-drug interaction based on drug transport alteration in humans. In the same way, putative pesticide-mediated alteration of endogenous 
substrate transport and possible deleterious consequences in response to environmental exposure may probably be discarded. By contrast, for pesticides recognized as substrates, transporters may be implicated in their toxicokinetics and their toxicity towards human health.

\section{Expert opinion}

Drug transporters are now considered as major actors of pharmacokinetics [7], which fully justify the study of drug-transporter interactions during the development of new molecular entities by pharmaceutical companies. Data reported above unambiguously indicate that some pesticides also interact with transporters, i.e., they can inhibit their activity, regulate their expression or be themselves substrates. This provides proof of concept that transporters should be considered when studying the toxicokinetics and toxicity of pesticides in humans. For transporter inhibition, the concentrations of pesticides in vitro blocking transporter activities have however to be confronted to the levels of unbound pesticides reached in humans in response to environmental exposure, in order to precise the in vivo relevance of such transporter inhibitions. Indeed, in most cases, the pesticide concentrations required to inhibit transporter may probably be much higher than pesticide blood concentrations reached in exposed humans. This likely discards any in vivo transporter inhibitions in response to environmental exposure to pesticides. In the same way, the in vivo relevance of the cisstimulation of some transporter activities by certain pesticides remains to be clarified.

Chemical pesticides remain much less studied than drugs with respect to interactions with transporters, with no or only limited data available for most pesticides. Further studies are therefore required to characterize pesticide-transporter interactions in a more extensive and systematic manner and to determine their possible implications in deleterious effects of pesticides towards human health. To do this, the use of high-throughput assay panels for human drug transporters may be welcome. Such assays, mainly based on fluorescent probes 
substrates for P-gp, MRPs, BCRP, OATPs, OATs and OCTs [111, 112], are fully applicable to large series of compounds tested at various concentrations and permit to reduce analysis costs. These functional assays may additionally provide structure-activity information, which may be useful for modeling quantitative structure-activity relationships (QSAR) with respect to interactions with transporters. Such QSAR studies may help to in silico predict inhibition of transporters by pesticides and/or handling of pesticides by transporters. QSAR approaches have already been applied with success to drug-transporter interactions, including those related to P-gp [113], MRP2 [114], BCRP [115], OCT1 [116], OATP1B1/1B3 [117] and OAT1/OAT3 [118]. Interestingly, molecular descriptors associated with OCT1 inhibition by pyrethroids have been determined and combining pairwise some of these descriptors allow to graphically and successfully predict interactions of imiprothrin, phenothrin and prallethrin with OCT1, OCT2, OATP2B1, OAT1 and OAT3 [18]. Besides, or together with QSAR studies, molecular docking analyses may constitute a valuable approach for predicting interaction of pesticides with transporters, as already established for drugs [119]. Overall, the application to pesticides of in silico tools developed for characterizing membrane permeability and transporter interactions with drugs, may represent a promising way, extending data and methods initially focused on drugs to the pesticide area. The graphical BOILED-Egg/SwissADME online method, based on lipophilicity and polarity and originally designed for drugs [120], has thus permitted to predict intestinal absorption and brain penetration of a large set of pesticides $(n=338)$ belonging to various chemical classes [121].

Genes encoding drug transporters are well-known to exhibit polymorphisms, which may have functional consequences, i.e., some genetic variants may display increased or decreased transport activity [122]. Such transporter polymorphisms concern most, if not all, drug transporters, including P-gp, BCRP, OATPs, OATS and OCTs. They are thought to be responsible for population-specific differences in drug transport and considerable inter- 
individual variation in physiology and pharmacotherapy [123]. In the context of environmental exposure to pesticides, such transporter polymorphisms may have to retain special attention. Indeed, they may result in inter-individual variation in toxicokinetics and toxicity of pesticides and may thus contribute in a notable way to individual susceptibility to these environmental pollutants. For example, subjects with genetic variants of $A B C B 1$ gene associated with low P-gp activity may have enhanced intestinal absorption and brain penetration of pesticides, by reduction of P-gp-mediated efflux of the chemicals at the intestinal and blood-brain barriers; such subjects may therefore be more susceptible to toxicity of pesticides. This hypothesis is fully supported by the fact that exposure to commonly used pesticides, specifically organochlorine and organophosphate insecticides, and the presence of variant $A B C B 1$ genotypes at two polymorphic sites, jointly increase the risk of Parkinson's disease [124].

The fact that pesticides are often used as mixtures of enantiomers has additionally to be taken into account when considering drug transporters and pesticides. Indeed, the stereoselectivity of chiral drug transport is well-established [125] and enantiomers of pesticides may therefore differentially interact with transporters. The handling of pesticides by SLC transporters distinct from main drug transporters, such as the L-type amino acid LAT1/2 (SLC7A5/SLC7A8) transporter or the dopamine transporter (DAT/SLC6A3), which handles glyphosate [126] or paraquat [66], respectively, also merits attention. In the same way, the molecular nature of the membrane transporters responsible for the established transepithelial transport of the herbicide 4-chloro-2-methylphenoxyacetic acid (MCPA) [127] and of the pyrethroids deltamethrin, cis-permethrin and trans-permethrin [41] across intestinal Caco-2 cells remains to be determined. The functional interplay between drug-metabolizing enzymes and transporters in pesticide absorption and disposition has additionally to be considered, as already done for drugs [128]. This interplay may notably correspond to 
preferential handling of pesticide metabolites by transporters, which suggests that pesticide metabolites may have to be investigated as potential transporter substrates and/or inhibitors. Additive or synergic effects towards transporters of pesticides in mixture with other pesticides or environmental contaminants constitute another important issue to apprehend. Finally, data about handling of pesticides by drug transporters may help to ameliorate the relevance and the accuracy of physiologically-based pharmacokinetic (PBPK) models, which represent promising approaches for pesticide risk assessment in humans [129, 130].

\section{References}

Papers of special note have been highlighted as either of interest $(\bullet)$ or of considerable interest $(\bullet \bullet)$ to readers.

1. Doring B, Petzinger E. Phase 0 and phase III transport in various organs: combined concept of phases in xenobiotic transport and metabolism. Drug Metab Rev. 2014 Aug;46(3):261-82. doi: 10.3109/03602532.2014.882353. PubMed PMID: 24483608; eng.

2. Colas C, Ung PM, Schlessinger A. SLC Transporters: Structure, Function, and Drug Discoyery. Medchemcomm. 2016 Jun 01;7(6):1069-1081. doi: 10.1039/c6md00005c. PubMed PMID: 27672436; PubMed Central PMCID: PMC5034948. eng.

3. Schinkel AH, Jonker JW. Mammalian drug efflux transporters of the ATP binding cassette (ABC) family: an overview. Adv Drug Deliv Rev. 2003 Jan 21;55(1):3-29. PubMed PMID: 12535572; eng. 
4. Giacomini KM, Huang SM, Tweedie DJ, et al. Membrane transporters in drug development. Nat Rev Drug Discov. 2010 Mar;9(3):215-36. doi: 10.1038/nrd3028. PubMed PMID: 20190787; PubMed Central PMCID: PMC3326076. eng.

5. Szakacs G, Varadi A, Ozvegy-Laczka C, et al. The role of ABC transporters in drug absorption, distribution, metabolism, excretion and toxicity (ADME-Tox). Drug Discov Today. 2008 May;13(9-10):379-93. doi: 10.1016/j.drudis.2007.12.010. PubMed PMID: 18468555; eng.

6. Shitara Y, Horie T, Sugiyama Y. Transporters as a determinant of drug clearance and tissue distribution. Eur J Pharm Sci. 2006 Apr;27(5):425-46. doi: 10.1016/j.ejps.2005.12.003. PubMed PMID: 16488580; eng.

7. Konig J, Muller F, Fromm MF. Transporters and drug-drug interactions: important determinants of drug disposition and effects, Pharmacol Rev. 2013 Jul;65(3):944-66. doi: 10.1124/pr.113.007518. PubMed PMID: 23686349; eng.

8. Prueksaritanont T, Chu X, Gibson C, et al. Drug-drug interaction studies: regulatory guidance and an industry perspective. AAPS J. 2013 Jul;15(3):629-45. doi: 10.1208/s12248-013-9470-x. PubMed PMID: 23543602; PubMed Central PMCID: PMC3691435. eng.

9. Abu-Qare AW, Elmasry E, Abou-Donia MB. A role for P-glycoprotein in environmental toxicology. J Toxicol Environ Health B Crit Rev. 2003 MayJun;6(3):279-88. doi: 10.1080/10937400306466. PubMed PMID: 12746142; eng.

10. Fardel O, Kolasa E, Le Vee M. Environmental chemicals as substrates, inhibitors or inducers of drug transporters: implication for toxicokinetics, toxicity and pharmacokinetics. Expert Opin Drug Metab Toxicol. 2012 Jan;8(1):29-46. doi: 10.1517/17425255.2012.637918. PubMed PMID: 22176607; eng. 
- A review summarizing interactions of environmental contaminants with drug transporters

11. Nicklisch SC, Rees SD, McGrath AP, et al. Global marine pollutants inhibit Pglycoprotein: Environmental levels, inhibitory effects, and cocrystal structure. Sci Adv. 2016 Apr;2(4):e1600001. doi: 10.1126/sciadv.1600001. PubMed PMID: 27152359; PubMed Central PMCID: PMC4846432. eng.

12. Bucher S, Le Vee M, Jouan E, et al. Regulation of hepatic drug transporter activity and expression by organochlorine pesticides. J Biochem Mol Toxicol. 2014 Mar;28(3):119-28. doi: 10.1002/jbt.21543. PubMed PMID: 24464585; eng.

- A study describing the interactions of organochlorine pesticides with drug transporter activity and expression

13. Maroni M, Fait A. Health effects in man from long-term exposure to pesticides. A review of the 1975-1991 literature. Toxicology. 1993 Mar;78(1-3):1-180. PubMed PMID: 8465354; eng.

14. Mostafalou S, Abdollahi M. Pesticides: an update of human exposure and toxicity. Arch Toxicol. 2017;91(2):549-599.

•• An interesting review about human exposure to pesticides and pesticide toxicity

15. Fardel O, Lecureur V, Guillouzo A. The P-glycoprotein multidrug transporter. Gen Pharmacol. 1996 Dec;27(8):1283-91. PubMed PMID: 9304397; eng.

16. Zhou SF. Structure, function and regulation of P-glycoprotein and its clinical relevance in drug disposition. Xenobiotica. 2008 Jul;38(7-8):802-32. doi: 10.1080/00498250701867889. PubMed PMID: 18668431; eng.

17. Bain LJ, LeBlanc GA. Interaction of structurally diverse pesticides with the human MDR1 gene product P-glycoprotein. Toxicol Appl Pharmacol. 1996 Nov;141(1):28898. doi: 10.1006/taap.1996.0286. PubMed PMID: 8917702; eng. 
-• A complete study bringing the proof of the concept that structurally diverse pesticides can interact with drug transporters

18. Chedik L, Bruyere A, Le Vee M, et al. Inhibition of Human Drug Transporter Activities by the Pyrethroid Pesticides Allethrin and Tetramethrin. PLoS One. 2017;12(1):e0169480. doi: 10.1371/journal.pone.0169480. PubMed PMID: 28099443; PubMed Central PMCID: PMC5242521. eng.

- A study reporting the effects of pyrethroids towards ABC and SLC transporter activities

19. Bain LJ, McLachlan JB, LeBlanc GA. Structure-activity relationships for xenobiotic transport substrates and inhibitory ligands of P-glycoprotein. Environ Health Perspect. 1997 Aug;105(8):812-8. PubMed PMID: 9347896; PubMed Central PMCID: PMC1470197. eng.

20. Lacher SE, Skagen K, Veit J, et al. P-Glycoprotein Transport of Neurotoxic Pesticides. J Pharmacol Exp Ther. 2015 Oct;355(1):99-107. doi: 10.1124/jpet.115.226373. PubMed PMID: 26272936; PubMed Central PMCID: PMC4576670. eng.

21. Pivcevic B, Zaja R. Pesticides and their binary combinations as P-glycoprotein inhibitors in NIH 3T3/MDR1 cells. Environ Toxicol Pharmacol. 2006 Nov;22(3):26876. doi: 10.1016/j.etap.2006.04.002. PubMed PMID: 21783720; eng.

\section{- The description of pesticide mixture effects towards P-gp activity}

22. Didier A, Loor F. The abamectin derivative ivermectin is a potent P-glycoprotein inhibitor. Anticancer Drugs. 1996 Sep;7(7):745-51. PubMed PMID: 8949985; eng.

23. Pouliot JF, L'Heureux F, Liu Z, et al. Reversal of P-glycoprotein-associated multidrug resistance by ivermectin. Biochem Pharmacol. 1997 Jan 10;53(1):17-25. PubMed PMID: 8960059; eng. 
24. Dalzell AM, Mistry P, Wright J, et al. Characterization of multidrug transportermediated efflux of avermectins in human and mouse neuroblastoma cell lines. Toxicol Lett. 2015 Jun 15;235(3):189-98. doi: 10.1016/j.toxlet.2015.04.005. PubMed PMID: 25865432; eng.

25. Mazur CS, Marchitti SA, Zastre J. P-glycoprotein inhibition by the agricultural pesticide propiconazole and its hydroxylated metabolites: Implications for pesticidedrug interactions. Toxicol Lett. 2015 Jan 5;232(1):37-45. doi: 10.1016/j.toxlet.2014.09.020. PubMed PMID: 25268938; eng.

26. Miyata K, Nakagawa Y, Kimura Y, et al. In vitro and in vivo evaluations of the Pglycoprotein-mediated efflux of dibenzoylhydrazines. Toxicol Appl Pharmacol. 2016 May 1;298:40-7. doi: 10.1016/j.taap.2016.03.008. PubMed PMID: 26995013; eng.

27. Sreeramulu K, Liu R, Sharom FJ. Interaction of insecticides with mammalian Pglycoprotein and their effect on its transport function. Biochim Biophys Acta. 2007 Jul;1768(7):1750-7. doi: 10.1016/j.bbamem.2007.04.001. PubMed PMID: 17490606; eng.

28. Oosterhuis B, Vukman K, Vagi E, et al. Specific interactions of chloroacetanilide herbicides with human ABC transporter proteins. Toxicology. 2008 Jun 3;248(1):4551. doi: 10.1016/j.tox,2008.03.003. PubMed PMID: 18433974; eng.

29. Staal RG, Yang JM, Hait WN, et al. Interactions of 1-methyl-4-phenylpyridinium and other compounds with P-glycoprotein: relevance to toxicity of 1-methyl-4-phenyl1,2,3,6-tetrahydropyridine. Brain Res. 2001 Aug 10;910(1-2):116-25. PubMed PMID: 11489261; eng.

30. Bircsak KM, Richardson JR, Aleksunes LM. Inhibition of human MDR1 and BCRP transporter ATPase activity by organochlorine and pyrethroid insecticides. J Biochem 
Mol Toxicol. 2013 Feb;27(2):157-64. doi: 10.1002/jbt.21458. PubMed PMID: 23169446; PubMed Central PMCID: PMC4001733. eng.

31. Wen X, Gibson CJ, Yang I, et al. MDR1 transporter protects against paraquat-induced toxicity in human and mouse proximal tubule cells. Toxicol Sci. 2014 Oct;141(2):47583. doi: 10.1093/toxsci/kfu141. PubMed PMID: 25015657; PubMed Central PMCID: PMC4271045. eng.

\section{- The demonstration of the protective role of P-gp towards paraquat toxicity}

32. Silva R, Sousa E, Carmo H, et al. Induction and activation of P-glycoprotein by dihydroxylated xanthones protect against the cytotoxicity of the P-glycoprotein substrate paraquat. Arch Toxicol. 2014 Apr;88(4):937-51. doi: 10.1007/s00204-0141193-y. PubMed PMID: 24464498; eng.

33. Vilas-Boas V, Silva R, Palmeira A, et al. Development of novel rifampicin-derived Pglycoprotein activators/inducers. synthesis, in silico analysis and application in the RBE4 cell model, using paraquat as substrate. PLoS One. 2013;8(8):e74425. doi: 10.1371/journal.pone.0074425. PubMed PMID: 23991219; PubMed Central PMCID: PMC3753303. eng.

34. Zerin T, Kim YS, Hong SY, et al. Protective effect of methylprednisolone on paraquat-induced A549 cell cytotoxicity via induction of efflux transporter, Pglycoprotein expression. Toxicol Lett. 2012 Jan 25;208(2):101-7. doi: 10.1016/j.toxlet.2011.10.019. PubMed PMID: 22079615; eng.

35. Dinis-Oliveira RJ, Remiao F, Duarte JA, et al. P-glycoprotein induction: an antidotal pathway for paraquat-induced lung toxicity. Free Radic Biol Med. 2006 Oct 15;41(8):1213-24. doi: 10.1016/j.freeradbiomed.2006.06.012. PubMed PMID: 17015168; eng. 
36. Lacher SE, Gremaud JN, Skagen K, et al. Absence of P-glycoprotein transport in the pharmacokinetics and toxicity of the herbicide paraquat. J Pharmacol Exp Ther. 2014 Feb;348(2):336-45. doi: 10.1124/jpet.113.209791. PubMed PMID: 24297779; PubMed Central PMCID: PMC3912546. eng.

37. Brayden DJ, Griffin J. Avermectin transepithelial transport in MDR1- and MRPtransfected canine kidney monolayers. Vet Res Commun. 2008 Jan;32(1):93-106. doi: 10.1007/s11259-007-9007-9. PubMed PMID: 17578674; eng.

38. Lespine A, Dupuy J, Orlowski S, et al. Interaction of ivermectin with multidrug resistance proteins (MRP1, 2 and 3). Chem Biol Interact. 2006 Feb 25;159(3):169-79. doi: 10.1016/j.cbi.2005.11.002. PubMed PMID: 16384552; eng.

39. Schinkel AH, Smit JJ, van Tellingen O, et al. Disruption of the mouse mdrla Pglycoprotein gene leads to a deficiency in the blood-brain barrier and to increased sensitivity to drugs. Cell. 1994 May 20;77(4):491-502. PubMed PMID: 7910522; eng.

40. Yazdian S, Fahham N, Ghahremani MH, et al. Evaluation of the expression of Pglycoprotein in propoxur-resistant Caco-2 cells. Acta Med Iran. 2014;52(10):728-33. PubMed PMID: 25369005; eng.

41. Zastre J, Dowd C, Bruckner J, et al. Lack of P-glycoprotein-mediated efflux and the potential involvement of an influx transport process contributing to the intestinal uptake of deltamethrin, cis-permethrin, and trans-permethrin. Toxicol Sci. 2013 Dec;136(2):284-93. doi: 10.1093/toxsci/kft193. PubMed PMID: 24014652; eng.

•- A study reporting the passage of some pyrethroids across the intestinal barrier

42. Gschwind L, Rollason V, Daali Y, et al. Role of P-glycoprotein in the uptake/efflux transport of oral vitamin $\mathrm{K}$ antagonists and rivaroxaban through the Caco-2 cell model. Basic Clin Pharmacol Toxicol. 2013 Oct;113(4):259-65. doi: 10.1111/bcpt.12084. PubMed PMID: 23663291; eng. 
43. Martel F, Ribeiro L, Calhau C, et al. Characterization of the efflux of the organic cation MPP+ in cultured rat hepatocytes. Eur J Pharmacol. 1999 Aug 27;379(23):211-8. PubMed PMID: 10497908; eng.

44. Martel F, Calhau C, Azevedo I. Characterization of the transport of the organic cation $[3 \mathrm{H}] \mathrm{MPP}+$ in human intestinal epithelial (Caco-2) cells. Naunyn Schmiedebergs Arch Pharmacol. 2000 May;361(5):505-13. PubMed PMID: 10832604; eng.

45. Slot AJ, Molinski SV, Cole SP. Mammalian multidrug-resistance proteins (MRPs). Essays Biochem. 2011 Sep 7;50(1):179-207. doi: 10.1042/bse0500179. PubMed PMID: 21967058; eng.

46. Cole SP. Multidrug resistance protein 1 (MRP1, ABCC1), a "multitasking" ATPbinding cassette (ABC) transporter. J Biol Chem. 2014 Nov 7;289(45):30880-8. doi: 10.1074/jbc.R114.609248. PubMed PMID: 25281745; PubMed Central PMCID: PMC4223294. eng.

47. Keppler D. Multidrug resistance proteins (MRPs, ABCCs): importance for pathophysiology and drug therapy. Handb Exp Pharmacol. 2011 (201):299-323. doi: 10.1007/978-3-642-14541-4_8. PubMed PMID: 21103974; eng.

48. Malofeeva EV, Domanitskaya N, Gudima M, et al. Modulation of the ATPase and transport activities of broad-acting multidrug resistance factor ABCC10 (MRP7). Cancer Res. 2012 Dec 15;72(24):6457-67. doi: 10.1158/0008-5472.can-12-1340. PubMed PMID: 23087055; PubMed Central PMCID: PMC3525726. eng.

49. Oguri T, Bessho Y, Achiwa H, et al. MRP8/ABCC11 directly confers resistance to 5fluorouracil. Mol Cancer Ther. 2007 Jan;6(1):122-7. doi: 10.1158/1535-7163.mct-060529. PubMed PMID: 17237272; eng. 
50. Tribull TE, Bruner RH, Bain LJ. The multidrug resistance-associated protein 1 transports methoxychlor and protects the seminiferous epithelium from injury. Toxicol Lett. 2003 Apr 30;142(1-2):61-70. PubMed PMID: 12765240; eng.

\section{- The demonstration of the interaction of Mrp1 with methoxychlor}

51. Jani M, Ambrus C, Magnan R, et al. Structure and function of BCRP, a broad specificity transporter of xenobiotics and endobiotics. Arch Toxicol. 2014 Jun;88(6):1205-48. doi: 10.1007/s00204-014-1224-8. PubMed PMID: 24777822; eng.

52. Matsuo H, Takada T, Ichida K, et al. Common defects of ABCG2, a high-capacity urate exporter, cause gout: a function-based genetic analysis in a Japanese population. Sci Transl Med. 2009 Nov 4;1(5):5ra11. doi: 10.1126/scitranslmed.3000237. PubMed PMID: 20368174; eng.

53. Halwachs S, Schafer I, Kneuer C, et al. Assessment of ABCG2-mediated transport of pesticides across the rabbit placenta barrier using a novel MDCKII in vitro model. Toxicol Appl Pharmacol. 2016 Aug 15;305:66-74. doi: 10.1016/j.taap.2016.06.007. PubMed PMID: 27288731; eng.

54. Yang MS, Yu CP, Chao PL, et al. R- and S-Warfarin Were Transported by Breast Cancer Resistance Protein: From In Vitro to Pharmacokinetic-Pharmacodynamic Studies. J Pharm Sci. 2017 May;106(5):1419-1425. doi: 10.1016/j.xphs.2017.01.012. PubMed PMID: 28093289; eng.

55. Geyer J, Gavrilova O, Petzinger E. Brain penetration of ivermectin and selamectin in mdrla,b P-glycoprotein- and bcrp- deficient knockout mice. J Vet Pharmacol Ther. 2009 Feb;32(1):87-96. doi: 10.1111/j.1365-2885.2008.01007.x. PubMed PMID: 19161460; eng.

56. Muenster U, Grieshop B, Ickenroth K, et al. Characterization of substrates and inhibitors for the in vitro assessment of Bcrp mediated drug-drug interactions. Pharm 
Res. 2008 Oct;25(10):2320-6. doi: 10.1007/s11095-008-9632-1. PubMed PMID: 18523872; eng.

57. Nies AT, Koepsell H, Damme K, et al. Organic cation transporters (OCTs, MATEs), in vitro and in vivo evidence for the importance in drug therapy. Handb Exp Pharmacol. 2011 (201):105-67. doi: 10.1007/978-3-642-14541-4_3. PubMed PMID: 21103969; eng.

58. Yonezawa A, Inui K. Organic cation transporter OCT/SLC22A and $\mathrm{H}(+) /$ organic cation antiporter MATE/SLC47A are key molecules for nephrotoxicity of platinum agents. Biochem Pharmacol. 2011 Mar 1;81(5):563-8. doi: 10.1016/j.bcp.2010.11.016. PubMed PMID: 21144842; eng.

59. Chedik L, Bruyere A, Fardel O. Interactions of organophosphorus pesticides with solute carrier (SLC) drug transporters. Xenobiotica. 2018 Mar 6:1-12. doi: 10.1080/00498254.2018.1442030. PubMed PMID: 29448871; eng.

60. Gorboulev V, Ulzheimer JC, Akhoundova A, et al. Cloning and characterization of two human polyspecific organic cation transporters. DNA Cell Biol. 1997 Jul;16(7):871-81. doi: 10.1089/dna.1997.16.871. PubMed PMID: 9260930; eng.

61. Wu X, Kekuda R, Huang W, et al. Identity of the organic cation transporter OCT3 as the extraneuronal monoamine transporter (uptake2) and evidence for the expression of the transporter in the brain. J Biol Chem. 1998 Dec 4;273(49):32776-86. PubMed PMID; 9830022; eng.

62. Otsuka M, Matsumoto T, Morimoto R, et al. A human transporter protein that mediates the final excretion step for toxic organic cations. Proc Natl Acad Sci U S A. 2005 Dec 13;102(50):17923-8. doi: 10.1073/pnas.0506483102. PubMed PMID: 16330770; PubMed Central PMCID: PMC1312386. eng. 
63. Masuda S, Terada T, Yonezawa A, et al. Identification and functional characterization of a new human kidney-specific H+/organic cation antiporter, kidney-specific multidrug and toxin extrusion 2. J Am Soc Nephrol. 2006 Aug;17(8):2127-35. doi: 10.1681/asn.2006030205. PubMed PMID: 16807400; eng.

64. Lee WK, Reichold M, Edemir B, et al. Organic cation transporters OCT1, 2, and 3 mediate high-affinity transport of the mutagenic vital dye ethidium in the kidney proximal tubule. Am J Physiol Renal Physiol. 2009 Jun;296(6):F1504-13. doi: 10.1152/ajprenal.90754.2008. PubMed PMID: 19357179; eng.

65. Chen Y, Zhang S, Sorani M, et al. Transport of paraquat by human organic cation transporters and multidrug and toxic compound extrusion family. J Pharmacol Exp Ther. 2007 Aug;322(2):695-700. doi: 10.1124/jpet.107.123554. PubMed PMID: 17495125; eng.

66. Rappold PM, Cui M, Chesser AS, et al. Paraquat neurotoxicity is mediated by the dopamine transporter and organic cation transporter-3. Proc Natl Acad Sci U S A. 2011 Dec 20;108(51):20766-71. doi: 10.1073/pnas.1115141108. PubMed PMID: 22143804; PubMed Central PMCID: PMC3251116. eng.

- A study reporting the role of the SLC transporter OCT3 in neurotoxicity of paraquat

67. Obaidat A, Roth M, Hagenbuch B. The expression and function of organic anion transporting polypeptides in normal tissues and in cancer. Annu Rev Pharmacol Toxicol. 2012;52:135-51. doi: 10.1146/annurev-pharmtox-010510-100556. PubMed PMID: 21854228; PubMed Central PMCID: PMC3257355. eng.

68. Wang L, Sweet DH. Renal organic anion transporters (SLC22 family): expression, regulation, roles in toxicity, and impact on injury and disease. AAPS J. 2013 
Jan;15(1):53-69. doi: 10.1208/s12248-012-9413-y. PubMed PMID: 23054972; PubMed Central PMCID: PMC3535093. eng.

69. Konig J. Uptake transporters of the human OATP family: molecular characteristics, substrates, their role in drug-drug interactions, and functional consequences of polymorphisms. Handb Exp Pharmacol. 2011 (201):1-28. doi: 10.1007/978-3-64214541-4_1. PubMed PMID: 21103967; eng.

70. Burckhardt G. Drug transport by Organic Anion Transporters (OATs). Pharmacol Ther. 2012 Oct;136(1):106-30. doi: 10.1016/j.pharmthera.2012.07.010. PubMed PMID: 22841915; eng.

71. Nozaki Y, Kusuhara H, Kondo T, et al. Characterization of the uptake of organic anion transporter (OAT) 1 and OAT3 substrates by human kidney slices. J Pharmacol Exp Ther. 2007 Apr;321(1):362-9. doi: 10.1124/jpet.106.113076. PubMed PMID: 17255469; eng.

72. Hodgson E, Rose RL. Human metabolic interactions of environmental chemicals. J Biochem Mol Toxicol. 2007;21(4):182-6. PubMed PMID: 17936932; eng.

73. Abass K, Lamsa V, Reponen P, et al. Characterization of human cytochrome P450 induction by pesticides. Toxicology. 2012 Mar 29;294(1):17-26. doi: 10.1016/j.tox.2012.01.010. PubMed PMID: 22310298; eng.

74. Kretschmer XC, Baldwin WS. CAR and PXR: xenosensors of endocrine disrupters? Chem Biol Interact. 2005 Aug 15;155(3):111-28. doi: 10.1016/j.cbi.2005.06.003. PubMed PMID: 16054614; eng.

75. Staudinger JL, Madan A, Carol KM, et al. Regulation of drug transporter gene expression by nuclear receptors. Drug Metab Dispos. 2003 May;31(5):523-7. PubMed PMID: 12695338; eng.

\section{- An interesting review about transporter regulation by nuclear receptors}


76. Geick A, Eichelbaum M, Burk O. Nuclear receptor response elements mediate induction of intestinal MDR1 by rifampin. J Biol Chem. 2001 May 4;276(18):145817. doi: 10.1074/jbc.M010173200. PubMed PMID: 11297522; eng.

77. Kast HR, Goodwin B, Tarr PT, et al. Regulation of multidrug resistance-associated protein $2(\mathrm{ABCC} 2)$ by the nuclear receptors pregnane $\mathrm{X}$ receptor, farnesoid $\mathrm{X}$ activated receptor, and constitutive androstane receptor. J Biol Chem. 2002 Jan 25;277(4):2908-15. doi: 10.1074/jbc.M109326200. PubMed PMID: 11706036; eng.

78. Teng S, Jekerle V, Piquette-Miller M. Induction of ABCC3 (MRP3) by pregnane X receptor activators. Drug Metab Dispos. 2003 Nov;31(11):1296-9. doi: 10.1124/dmd.31.11.1296. PubMed PMID: 14570758; eng.

79. Whyte-Allman SK, Hoque MT, Jenabian MA, et al. Xenobiotic Nuclear Receptors Pregnane X Receptor and Constitutive Androstane Receptor Regulate Antiretroviral Drug Efflux Transporters at the Blood-Testis Barrier. J Pharmacol Exp Ther. 2017 Dec;363(3):324-335. doi: 10.1124/jpet.117.243584. PubMed PMID: 28970358; eng.

80. Austin G, Holcroft A, Rinne N, et al. Evidence that the pregnane $\mathrm{X}$ and retinoid receptors PXR, RAR and RXR may regulate transcription of the transporter hOCT1 in chronic myeloid leukaemia cells. Eur J Haematol. 2015 Jan;94(1):74-8. doi: 10.1111/ejh.12409. PubMed PMID: 25039279; eng.

81. Cerveny L, Svecova L, Anzenbacherova E, et al. Valproic acid induces CYP3A4 and MDR1 gene expression by activation of constitutive androstane receptor and pregnane X receptor pathways. Drug Metab Dispos. 2007 Jul;35(7):1032-41. doi: 10.1124/dmd.106.014456. PubMed PMID: 17392393; eng.

82. Burk O, Arnold KA, Geick A, et al. A role for constitutive androstane receptor in the regulation of human intestinal MDR1 expression. Biol Chem. 2005 Jun;386(6):50313. doi: 10.1515/bc.2005.060. PubMed PMID: 16006237; eng. 
83. Wang X, Sykes DB, Miller DS. Constitutive androstane receptor-mediated upregulation of ATP-driven xenobiotic efflux transporters at the blood-brain barrier. Mol Pharmacol. 2010 Sep;78(3):376-83. doi: 10.1124/mol.110.063685. PubMed PMID: 20547735; PubMed Central PMCID: PMC2939489. eng.

84. Wagner M, Halilbasic E, Marschall HU, et al. CAR and PXR agonists stimulate hepatic bile acid and bilirubin detoxification and elimination pathways in mice. Hepatology. 2005 Aug;42(2):420-30. doi: 10.1002/hep.20784. PubMed PMID: 15986414; eng.

85. Ananthanarayanan M, Balasubramanian N, Makishima M, et al. Human bile salt export pump promoter is transactivated by the farnesoid $\mathrm{X}$ receptor/bile acid receptor. J Biol Chem. 2001 Aug 3;276(31):28857-65. doi: 10.1074/jbc.M011610200. PubMed PMID: 11387316; eng.

86. Lemaire G, de Sousa G, Rahmani R. A PXR reporter gene assay in a stable cell culture system: CYP3A4 and CYP2B6 induction by pesticides. Biochem Pharmacol. 2004 Dec 15;68(12):2347-58. doi: 10.1016/j.bcp.2004.07.041. PubMed PMID: 15548381; eng.

87. Baldwin WS, Roling JA. A concentration addition model for the activation of the constitutive androstane receptor by xenobiotic mixtures. Toxicol Sci. 2009 Jan;107(1):93-105. doi: 10.1093/toxsci/kfn206. PubMed PMID: 18832183; PubMed Central PMCID: PMC2735418. eng.

88. Ridano ME, Racca AC, Flores-Martin JB, et al. Impact of chlorpyrifos on human villous trophoblasts and chorionic villi. Toxicol Appl Pharmacol. 2017 Aug 15;329:26-39. doi: 10.1016/j.taap.2017.05.026. PubMed PMID: 28549829; eng. 
89. Geenes VL, Dixon PH, Chambers J, et al. Characterisation of the nuclear receptors FXR, PXR and CAR in normal and cholestatic placenta. Placenta. 2011 Jul;32(7):5357. doi: 10.1016/j.placenta.2011.04.014. PubMed PMID: 21596433; eng.

90. Roques BB, Leghait J, Lacroix MZ, et al. The nuclear receptors pregnane X receptor and constitutive androstane receptor contribute to the impact of fipronil on hepatic gene expression linked to thyroid hormone metabolism. Biochem Pharmacol. 2013 Oct 1;86(7):997-1039. doi: 10.1016/j.bcp.2013.08.012. PubMed PMID: 23962444; eng.

91. Rotroff DM, Beam AL, Dix DJ, et al. Xenobiotic-metabolizing enzyme and transporter gene expression in primary cultures of human hepatocytes modulated by ToxCast chemicals. J Toxicol Environ Health B Crit Rev. 2010 Feb;13(2-4):329-46. doi: 10.1080/10937404.2010.483949. PubMed PMID: 20574906; eng.

- A study analyzing the effects of pesticides on drug transporter expression in primary human hepatocytes

92. Menez C, Mselli-Lakhal L, Foucaud-Vignault $\mathrm{M}$, et al. Ivermectin induces Pglycoprotein expression and function through mRNA stabilization in murine hepatocyte cell line. Biochem Pharmacol. 2012 Jan 15;83(2):269-78. doi: 10.1016/j.bcp.2011.10.010. PubMed PMID: 22024132; eng.

93. Lecoeur S, Videmann B, Mazallon M. Effect of organophosphate pesticide diazinon on expression and activity of intestinal P-glycoprotein. Toxicol Lett. 2006 Mar 1;161(3):200-9. doi: 10.1016/j.toxlet.2005.09.003. PubMed PMID: 16221533; eng.

94. de Lima Toccafondo Vieira M, Tagliati CA. Hepatobiliary transporters in druginduced cholestasis: a perspective on the current identifying tools. Expert Opin Drug Metab Toxicol. 2014 Apr;10(4):581-97. doi: 10.1517/17425255.2014.884069. PubMed PMID: 24588537; eng. 
95. Zhang L, Zhang YD, Strong JM, et al. A regulatory viewpoint on transporter-based drug interactions. Xenobiotica. 2008 Jul;38(7-8):709-24. doi: 10.1080/00498250802017715. PubMed PMID: 18668428; eng.

96. Glynn AW, Wolk A, Aune M, et al. Serum concentrations of organochlorines in men: a search for markers of exposure. Sci Total Environ. 2000 Dec 18;263(1-3):197-208. PubMed PMID: 11194153; eng.

97. Leng G, Ranft U, Sugiri D, et al. Pyrethroids used indoors--biological monitoring of exposure to pyrethroids following an indoor pest control operation. Int J Hyg Environ Health. 2003 Mar;206(2):85-92. doi: 10.1078/1438-4639-00199. PubMed PMID: 12708229; eng.

98. Ruiz-Suarez LE, Castro-Chan RA, Rivero-Perez NE, et al. Levels of organochlorine pesticides in blood plasma from residents of malaria-endemic communities in Chiapas, Mexico. Int J Environ Res Public Health. 2014 Oct 10;11(10):10444-60. doi: 10.3390/ijerph111010444. PubMed PMID: 25310541; PubMed Central PMCID: PMC4210989. eng.

99. Gulden M, Morchel S, Tahan S, et al. Impact of protein binding on the availability and cytotoxic potency of organochlorine pesticides and chlorophenols in vitro. Toxicology.2002 Jun 14;175(1-3):201-13. PubMed PMID: 12049848; eng.

100. McMullin TS, Brzezicki JM, Cranmer BK, et al. Pharmacokinetic modeling of disposition and time-course studies with [14C]atrazine. J Toxicol Environ Health A. 2003 May 23;66(10):941-64. doi: 10.1080/15287390306454. PubMed PMID: 12825238; eng.

101. Lanning CL, Fine RL, Sachs CW, et al. Chlorpyrifos oxon interacts with the mammalian multidrug resistance protein, P-glycoprotein. J Toxicol Environ Health. 
1996 Mar;47(4):395-407. doi: 10.1080/009841096161726. PubMed PMID: 8600291; eng.

102. Koepsell H. Role of organic cation transporters in drug-drug interaction. Expert Opin Drug Metab Toxicol. 2015;11(10):1619-33. doi: 10.1517/17425255.2015.1069274. PubMed PMID: 26206523; eng.

103. Clarivet B, Robin P, Pers YM, et al. Tocilizumab and mesenteric arterial thrombosis: drug-drug interaction with anticoagulants metabolized by CYP 450 and/or by Pglycoprotein. Eur J Clin Pharmacol. 2016 Nov;72(11):1413-1414. doi: 10.1007/s00228-016-2107-0. PubMed PMID: 27457374; eng.

104. Pang KS, Maeng HJ, Fan J. Interplay of transporters and enzymes in drug and metabolite processing. Mol Pharm. 2009 Nov-Dec;6(6):1734-55. doi: 10.1021/mp900258z. PubMed PMID: 19891494; eng.

- An interesting review about the interplay of transporters and enzymes

105. Murakami T, Takano M. Intestinal efflux transporters and drug absorption. Expert Opin Drug Metab Toxicol. 2008 Jul;4(7):923-39. doi: 10.1517/17425255.4.7.923. PubMed PMID: 18624680; eng.

106. Benet LZ. The role of BCS (biopharmaceutics classification system) and BDDCS (biopharmaceutics drug disposition classification system) in drug development. J Pharm Sci. 2013 Jan;102(1):34-42. doi: 10.1002/jps.23359. PubMed PMID: 23147500; PubMed Central PMCID: PMC3684558. eng.

107. Hong GL, Liu JM, Zhao GJ, et al. Cycloartenyl Ferulate Inhibits Paraquat-Induced Apoptosis in HK-2 Cells With the Involvement of ABCC1. J Cell Biochem. 2016 Apr;117(4):872-80. doi: 10.1002/jcb.25370. PubMed PMID: 26358524; eng. 
108. Gott RC, Kunkel GR, Zobel ES, et al. Implicating ABC Transporters in Insecticide Resistance: Research Strategies and a Decision Framework. J Econ Entomol. 2017 Apr 1;110(2):667-677. doi: 10.1093/jee/tox041. PubMed PMID: 28334260; eng.

109. Niedermeyer TH, Daily A, Swiatecka-Hagenbruch M, et al. Selectivity and potency of microcystin congeners against OATP1B1 and OATP1B3 expressing cancer cells. PLoS One. 2014;9(3):e91476. doi: 10.1371/journal.pone.0091476. PubMed PMID: 24614281; PubMed Central PMCID: PMC3948918. eng.

110. Zurawell RW, Chen H, Burke JM, et al. Hepatotoxic cyanobacteria: a review of the biological importance of microcystins in freshwater environments. J Toxicol Environ Health B Crit Rev. 2005 Jan-Feb;8(1):1-37. doi: 10.1080/10937400590889412. PubMed PMID: 15762553; eng.

111. Tang H, Shen DR, Han YH, et al. Development of novel, 384-well high-throughput assay panels for human drug transporters: drug interaction and safety assessment in support of discovery research. J Biomol Screen. 2013 Oct;18(9):1072-83. doi: 10.1177/1087057113494807. PubMed PMID: 24062352; eng.

112. Fardel O, Le Vee M, Jouan E, et al. Nature and uses of fluorescent dyes for drug transporter studies. Expert Opin Drug Metab Toxicol. 2015;11(8):1233-51. doi: 10.1517/17425255.2015.1053462. PubMed PMID: 26050735; eng.

113. Crivori P, Reinach B, Pezzetta D, et al. Computational models for identifying potential P-glycoprotein substrates and inhibitors. Mol Pharm. 2006 Jan-Feb;3(1):33-44. PubMed PMID: 16686367; eng.

114. Pedersen JM, Matsson P, Bergstrom CA, et al. Prediction and identification of drug interactions with the human ATP-binding cassette transporter multidrug-resistance associated protein 2 (MRP2; ABCC2). J Med Chem. 2008 Jun 12;51(11):3275-87. doi: 10.1021/jm7015683. PubMed PMID: 18457386; eng. 
115. Saito H, Hirano H, Nakagawa H, et al. A new strategy of high-speed screening and quantitative structure-activity relationship analysis to evaluate human ATP-binding cassette transporter ABCG2-drug interactions. J Pharmacol Exp Ther. 2006 Jun;317(3):1114-24. doi: 10.1124/jpet.105.099036. PubMed PMID: 16489126; eng.

116. Chen EC, Khuri N, Liang X, et al. Discovery of Competitive and Noncompetitive Ligands of the Organic Cation Transporter 1 (OCT1; SLC22A1). J Med Chem. 2017 Apr 13;60(7):2685-2696. doi: 10.1021/acs.jmedchem.6b01317. PubMed PMID: 28230985; eng.

117. De Bruyn T, van Westen GJ, Ijzerman AP, et al. Structure-based identification of OATP1B1/3 inhibitors. Mol Pharmacol. 2013 Jun;83(6):1257-67. doi: 10.1124/mol.112.084152. PubMed PMID: 23571415; eng.

118. Duan P, Li S, Ai N, et al. Potent inhibitors of human organic anion transporters 1 and 3 from clinical drug libraries: discovery and molecular characterization. Mol Pharm. 2012 Nov 5;9(11):3340-6. doi: 10.1021/mp300365t. PubMed PMID: 22973893; PubMed Central PMCID: PMC3490050. eng.

119. Chen L, Li Y, Yu H, et al. Computational models for predicting substrates or inhibitors of P-glycoprotein. Drug Discov Today. 2012 Apr;17(7-8):343-51. doi: 10.1016/j.drudis.2011.11.003. PubMed PMID: 22119877; eng.

- A review about the prediction of $P$-gp-chemical interactions by computational approaches

120. Daina A, Michielin O, Zoete V. SwissADME: a free web tool to evaluate pharmacokinetics, drug-likeness and medicinal chemistry friendliness of small molecules. Sci Rep. 2017 Mar 3;7:42717. doi: 10.1038/srep42717. PubMed PMID: 28256516; PubMed Central PMCID: PMC5335600. eng. 
121. Chedik L, Mias-Lucquin D, Bruyere A, et al. In Silico Prediction for Intestinal Absorption and Brain Penetration of Chemical Pesticides in Humans [Journal]. Int $\mathbf{J}$ Environ Res Public Health. 2017;14(7).

- A study using in silico approach for predicting the transport of pesticides across cellular barriers

122. Sissung TM, Troutman SM, Campbell TJ, et al. Transporter pharmacogenetics: transporter polymorphisms affect normal physiology, diseases, and pharmacotherapy. Discov Med. 2012 Jan;13(68):19-34. PubMed PMID: 22284781; PubMed Central PMCID: PMC4006110. eng.

123. Ahmed S, Zhou Z, Zhou J, et al. Pharmacogenomics of Drug Metabolizing Enzymes and Transporters: Relevance to Precision Medicine. Genomics Proteomics Bioinformatics. 2016 Oct;14(5):298-313. doi: 10.1016/j.gpb.2016.03.008. PubMed PMID: 27729266; PubMed Central PMCID: PMC5093856. eng.

124. Narayan S, Sinsheimer JS, Paul KC, et al. Genetic variability in ABCB1, occupational pesticide exposure, and Parkinson's disease. Environ Res. 2015 Nov;143(Pt A):98106. doi: 10.1016/j.envres.2015.08.022. PubMed PMID: 26457621; PubMed Central PMCID: PMC4911423. eng.

125. Zhou Q, Yu LS, Zeng S. Stereoselectivity of chiral drug transport: a focus on enantiomer-transporter interaction. Drug Metab Rev. 2014 Aug;46(3):283-90. doi: 10.3109/03602532.2014.887094. PubMed PMID: 24796860; eng.

126. Xu J, Li G, Wang Z, et al. The role of L-type amino acid transporters in the uptake of glyphosate across mammalian epithelial tissues. Chemosphere. 2016 Feb;145:487-94. doi: 10.1016/j.chemosphere.2015.11.062. PubMed PMID: 26701683; eng.

127. Kimura O, Tsukagoshi K, Hayasaka M, et al. Transepithelial transport of 4-chloro-2methylphenoxyacetic acid (MCPA) across human intestinal Caco-2 cell monolayers. 
Basic Clin Pharmacol Toxicol. 2012 Jun;110(6):530-6. doi: 10.1111/j.17427843.2011.00850.x. PubMed PMID: 22181038; eng.

128. Shi S, Li Y. Interplay of Drug-Metabolizing Enzymes and Transporters in Drug Absorption and Disposition. Curr Drug Metab. 2014;15(10):915-41. PubMed PMID: 25828591; eng.

129. Lu C, Holbrook CM, Andres LM. The implications of using a physiologically based pharmacokinetic (PBPK) model for pesticide risk assessment. Environ Health Perspect. 2010 Jan;118(1):125-30. doi: 10.1289/ehp.0901144. PubMed PMID: 20056589; PubMed Central PMCID: PMC2831956. eng.

130. Knaak JB, Dary CC, Zhang X, et al. Parameters for pyrethroid insecticide QSAR and PBPK/PD models for human risk assessment. Rev Environ Contam Toxicol. 2012;219:1-114. doi: 10.1007/978-1-4614-3281-4_1. PubMed PMID: 22610175; eng.

\section{Legend to figure}

Figure 1. Accumulation of the pyrethroids allethrin and tetramethrin in OCT1- and OCT2transfected HEK293 cells 
(A) HEK293 cells transduced with MOCK (HEK-MOCK), OCT1 (HEK-OCT1) or OCT2 (HEK-OCT2) were incubated with $100 \mu \mathrm{M}$ allethrin or $100 \mu \mathrm{M}$ tetramethrin in the absence (untreated) or presence of the OCT1 inhibitor verapamil $(50 \mu \mathrm{M})$ or the OCT2 inhibitor amitriptyline $(100 \mu \mathrm{M})$ for $5 \mathrm{~min}$ at $37^{\circ} \mathrm{C}$. Intracellular accumulations of the pyrethroids were next determined by LC-MS/MS analysis and normalized to total protein content. (B) Cellular accumulation of the OCT1 substrate DAPI and the OCT2 substrate rhodamine 123 was determined as previously described [18], in the absence (untreated) or presence of verapamil or amitriptyline. (A, B) Data are the means \pm SEM of three independent experiments. F.A.U., fluorescence arbitrary unit. ***, $\mathrm{p}<0.001$ (ANOVA followed by Newman-Keuls posthoc test). 


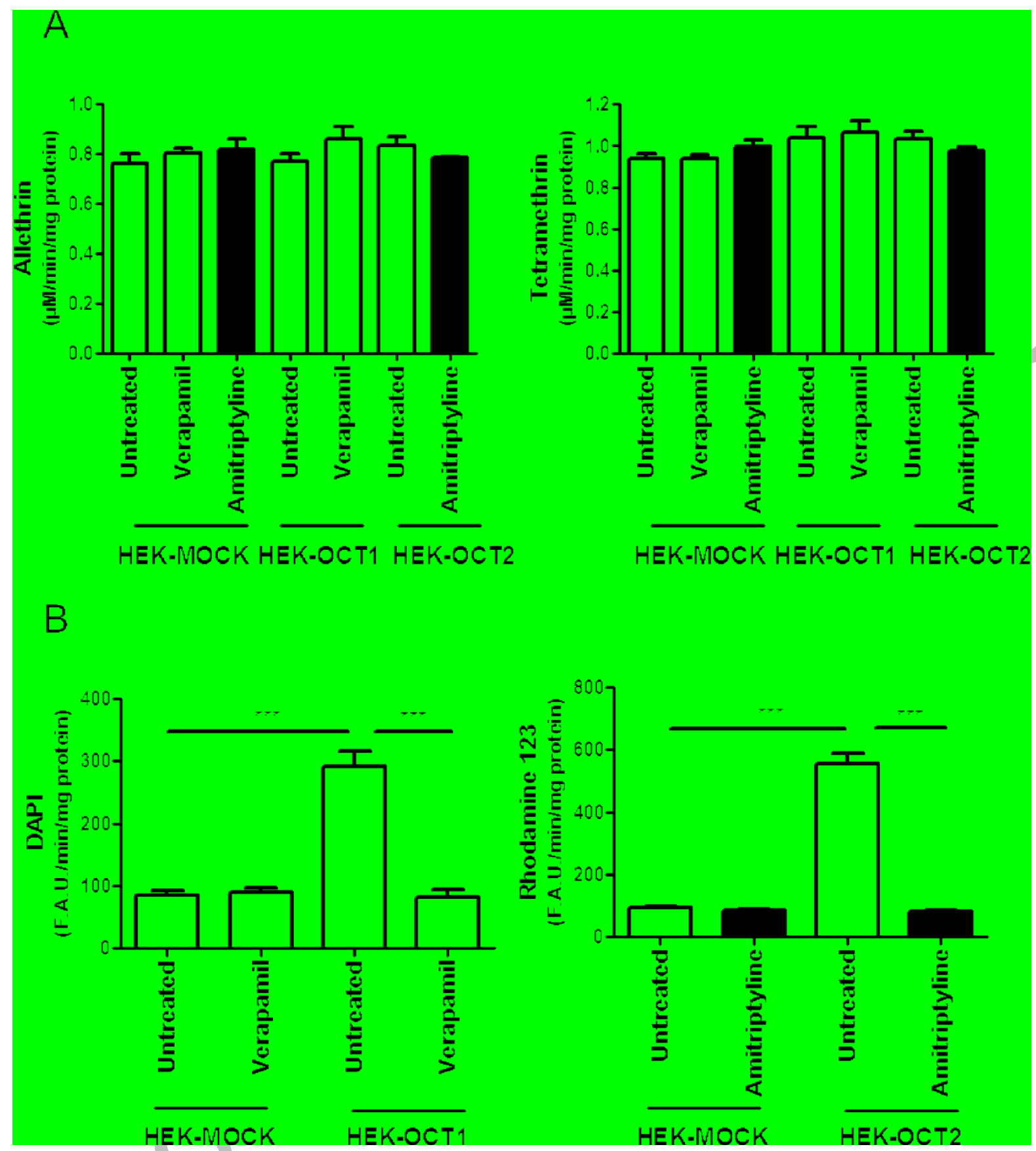


Table 1.Overview of the main classes of organic pesticide

\begin{tabular}{|c|c|c|c|c|}
\hline Pesticide class & Pesticide examples & $\begin{array}{l}\text { Main type of } \\
\text { activity }\end{array}$ & $\begin{array}{l}\text { Mechanism of } \\
\text { action }\end{array}$ & Comments \\
\hline $\begin{array}{l}\text { Organophosphorus } \\
\text { compounds }\end{array}$ & $\begin{array}{l}\text { Chlorpyrifos, malathion, } \\
\text { diazinon, dichlorvos }\end{array}$ & Insecticide & $\begin{array}{c}\text { Irreversible } \\
\text { acetylcholinesterase } \\
\text { inhibition }\end{array}$ & $\begin{array}{l}\text { Among the most used } \\
\text { insecticides }\end{array}$ \\
\hline Carbamates & Aldicarb, carbaryl, propoxur, & Insecticide & $\begin{array}{c}\text { Reversible } \\
\text { acetylcholinesterase } \\
\text { inhibition } \\
\end{array}$ & $\begin{array}{l}\mathrm{N} \text {-methylcarbamates for the } \\
\text { majority }\end{array}$ \\
\hline Pyrethroids & $\begin{array}{l}\text { Allethrin, deltamethrin, } \\
\text { resmethrin, cypermethrin }\end{array}$ & Insecticide & $\begin{array}{l}\text { Voltage-sensitive sodium } \\
\text { channel disruption }\end{array}$ & $\begin{array}{l}\text { Among the most used } \\
\text { insecticides }\end{array}$ \\
\hline $\begin{array}{l}\text { Organochlorine } \\
\text { compounds }\end{array}$ & $\begin{array}{l}\text { DDT, chlordane, aldrin, } \\
\text { endrin, dieldrin, heptachlor, } \\
\text { lindane, mirex, chlordecone }\end{array}$ & Insecticide & $\begin{array}{c}\text { Alteration of the } \\
\text { electrophysiological } \\
\text { properties of cell } \\
\text { membranes (particularly } \\
\text { nerve axons) }\end{array}$ & $\begin{array}{l}\text { Banned from most } \\
\text { countries, but exposure } \\
\text { continues due to high } \\
\text { remanence of } \\
\text { organochlorine pesticides }\end{array}$ \\
\hline Rotenoids & Rotenone & Insecticide & $\begin{array}{l}\text { mitochondrial respiratory } \\
\text { chain inhibition }\end{array}$ & \\
\hline $\begin{array}{l}\text { Nicotine and } \\
\text { neonicotinoids }\end{array}$ & $\begin{array}{l}\text { Nicotine, imidacloprid, } \\
\text { thiacloprid, acetamiprid, } \\
\text { nitenpyram }\end{array}$ & Insecticide & $\begin{array}{l}\text { Activation of the nicotinic } \\
\text { acetylcholine receptor }\end{array}$ & \\
\hline Formadinines & Chlordimeform, amitraz & Insecticide & $\begin{array}{l}\text { Activation of octopamine } \\
\text { receptor (insects) or } \alpha_{2^{-}} \\
\text {adrenergic receptor } \\
\text { (mammals) }\end{array}$ & \\
\hline Phenylpyrazoles & Fipronil & Insecticide & $\begin{array}{l}\text { Blockage of } \mathrm{GABA}_{\mathrm{A}} \text {-gated } \\
\text { chloride channel }\end{array}$ & \\
\hline Avermectins & Ivermectin & $\begin{array}{l}\text { Insecticide/ } \\
\text { antiparasitic }\end{array}$ & $\begin{array}{l}\text { Activation of glutamate- } \\
\text { dependent chloride } \\
\text { channels }\end{array}$ & \\
\hline Miscellaneous & $\begin{array}{c}\text { N,N-diethyl-3- } \\
\text { methylbenzamide (DEET) }\end{array}$ & ent & $\begin{array}{l}\text { Inhibition of olfactory } \\
\text { receptors of insecticides }\end{array}$ & $\begin{array}{c}30 \% \text { of the USA population } \\
\text { uses DEET every year }\end{array}$ \\
\hline $\begin{array}{l}\text { Phenoxy } \\
\text { Compounds }\end{array}$ & $\begin{array}{l}\text { 2,4-dichlorophenoxyacetic } \\
\text { acid }(2,4-\mathrm{D}), 2,4,5- \\
\text { trichlorophenoxyacetic acid } \\
(2,4,5-\mathrm{T}), 4 \text {-chloro- } 2- \\
\text { methylphenoxyacetic acid } \\
\text { (MCPA), fluazifop-butyl }\end{array}$ & Herbicide & Chemical analogs of auxin & $\begin{array}{l}\text { Among the most used } \\
\text { herbicides }\end{array}$ \\
\hline Bipyridil compounds & Paraquat, diquat & Herbicide & Photosynthesis inhibition & $\begin{array}{l}\text { Among the most commonly } \\
\text { used herbicides }\end{array}$ \\
\hline Chloroacetanilides & $\begin{array}{l}\text { Alachlor, acetochlor, } \\
\text { metolachlor, methoxychlor }\end{array}$ & Herbicide & $\begin{array}{l}\text { Inhibition of cyclisation } \\
\text { enzymes, part of the } \\
\text { gibberellin pathway }\end{array}$ & \\
\hline Triazines & Atrazine, simazine, propazine & Herbicide & $\begin{array}{l}\text { Inhibition of } \\
\text { photosynthesis }\end{array}$ & \\
\hline $\begin{array}{l}\text { Phosphonomethyl } \\
\text { amino acids }\end{array}$ & Glyphosate, glufosinate & Herbicide & $\begin{array}{l}\text { Inhibition of amino acid } \\
\text { synthesis }\end{array}$ & $\begin{array}{l}\text { Most widely used } \\
\text { herbicides worldwide }\end{array}$ \\
\hline Phenylurea & Diuron & Herbicide & $\begin{array}{c}\text { Inhibition of } \\
\text { photosynthesis }\end{array}$ & \\
\hline $\begin{array}{c}\text { Chloroalkylthiol } \\
\text { fungicides }\end{array}$ & Captan, folpet & Fungicide & $\begin{array}{l}\text { Thiol reactant inhibiting } \\
\text { respiration }\end{array}$ & \\
\hline Dithiocarbamates & $\begin{array}{l}\text { Maneb, ziram, zineb, } \\
\text { mancozeb, thiram }\end{array}$ & Fungicide & Release of carbon disulfide & $\begin{array}{c}\text { Often associated with metal } \\
\text { cations }\end{array}$ \\
\hline $\begin{array}{l}\text { Halogenated } \\
\text { benzonitrile }\end{array}$ & Chlorothalonil & Fungicide & $\begin{array}{l}\text { Reduction of fungal } \\
\text { intracellular glutathione } \\
\text { molecules to alternate } \\
\text { forms }\end{array}$ & $\begin{array}{l}\text { Among the most used } \\
\text { fungicide in the USA }\end{array}$ \\
\hline Benzimidazoles & Benomyl, carbendazim & Fungicide & $\begin{array}{l}\text { Inhibition of fungal growth } \\
\text { by tubulin binding }\end{array}$ & \\
\hline Azols & $\begin{array}{l}\text { Clotrimazole, propiconazole, } \\
\text { Epoxiconazole, enilconazole }\end{array}$ & Fungicide & $\begin{array}{l}\text { Inhibition of lanosterol } 14 \\
\alpha \text {-demethylase }\end{array}$ & \\
\hline Dicarboximides & Vinclozolin & Fungicide & Lipid synthesis inhibition & Banned in several countries \\
\hline $\begin{array}{c}\text { Coumarines/ } \\
\text { indan-1,3 -dione } \\
\text { derivatives }\end{array}$ & Warfarin, diphacinone & Rodenticide & $\begin{array}{l}\text { Anticoagulant/ } \\
\text { Anti-vitamin K }\end{array}$ & \\
\hline
\end{tabular}


Table 2. Classification of main drug transporters

\begin{tabular}{|c|c|c|c|}
\hline Transporter family & Transporter & Main expression & $\begin{array}{c}\text { Main type of } \\
\text { substrates }\end{array}$ \\
\hline \multirow[t]{2}{*}{ ABCB } & P-gp $(A B C B 1)$ & $\begin{array}{l}\text { Intestine, liver, kidney, } \\
\text { blood-brain barrier }\end{array}$ & Hydrophobic compounds \\
\hline & $\operatorname{BSEP}(A B C B 11)$ & Liver & Bile acids \\
\hline \multirow{5}{*}{$\mathrm{ABCC}$} & MRP1 $(A B C C 1)$ & Ubiquitous & $\begin{array}{c}\text { Hydrophobic } \\
\text { compounds, hydrophilic } \\
\text { anions, conjugates }\end{array}$ \\
\hline & MRP2 (ABCC2) & Intestine, liver, kidney & $\begin{array}{c}\text { Hydrophilic anions, } \\
\text { conjugates }\end{array}$ \\
\hline & MRP3 $(A B C C 4)$ & Liver, kidney & $\begin{array}{c}\text { Hydrophilic anions, } \\
\text { conjugates }\end{array}$ \\
\hline & MRP4 (ABCC4) & $\begin{array}{l}\text { Liver, kidney, blood- } \\
\text { brain barrier }\end{array}$ & Nucleotides \\
\hline & MRP5 (ABCC5) & Ubiquitous & Nucleotides \\
\hline ABCG & $\mathrm{BCRP}(A B C G 2)$ & $\begin{array}{c}\text { Intestine, liver, kidney, } \\
\text { blood-brain barrier, } \\
\text { stem cells }\end{array}$ & $\begin{array}{l}\text { Hydrophobic } \\
\text { compounds, hydrophilic } \\
\text { anions, conjugates }\end{array}$ \\
\hline \multirow{3}{*}{ SLCO } & OATP1B1 (SLCOIBI) & Liver & Organic anions \\
\hline & OATP1B3 (SLCO1B3) & Liver & Organic anions \\
\hline & OATP2B1 $(S L C O 2 B 1)$ & Liver, intestine & Organic anions \\
\hline SLC10A & NTCP $(S L C 10 A 1)$ & Liver & Bile acids \\
\hline \multirow{6}{*}{ SLC22A } & OCT1 $(S L C 22 A 1)$ & Liver & Organic cations \\
\hline & OCT2 (SLC22A2) & Kidney & Organic cations \\
\hline & OCT3 $(S L C 22 A 3)$ & Ubiquitous & Organic cations \\
\hline & OAT1 (SLC22A6) & Kidney & Organic anions \\
\hline & OAT2 (SLC22A7) & Liver & Organic anions \\
\hline & OAT3 (SLC22A8) & Kidney & Organic anions \\
\hline \multirow{2}{*}{ SLC47A } & MATE1 (SLC47AI) & Liver, kidney & Organic cations \\
\hline & MATE2-K (SLC47A2) & Kidney & Organic cations \\
\hline
\end{tabular}


Table 3. Inhibitory effects of pesticides towards drug transporter activities according to organic pesticide classes.

\begin{tabular}{|c|c|c|c|c|c|}
\hline \multirow{2}{*}{ Transporter } & \multicolumn{5}{|c|}{$\begin{array}{c}\text { Percentage of inhibitory pesticides } \\
\text { (n= total number of tested pesticides })\end{array}$} \\
\hline & $\begin{array}{c}\text { Organophosphorus } \\
\text { pesticides }\end{array}$ & $\begin{array}{l}\text { Organochlorine } \\
\text { pesticides }\end{array}$ & Pyrethroids & Carbamates & Chloroacetanilides \\
\hline P-gp & $\begin{array}{c}76.9 \%(n=13) \\
{[17,19]}\end{array}$ & $\begin{array}{c}30.8 \%(n=13) \\
{[12,17]}\end{array}$ & $\begin{array}{c}0.0 \%(\mathrm{n}=14) \\
{[18]}\end{array}$ & $\begin{array}{c}0.0 \%(\mathrm{n}=6) \\
{[17]}\end{array}$ & $57.1 \%(n=7)[28]$ \\
\hline MRP1/MRP2 & No data & $50.0 \%(\mathrm{n}=8)[12]$ & $\begin{array}{c}14.3 \%(n=14) \\
{[18]}\end{array}$ & No data & $0.0 \%(n=7)[28]$ \\
\hline BCRP & $66.7 \%(n=3)[53]$ & $50.0 \%(\mathrm{n}=8)[12]$ & $\begin{array}{c}14.3 \%(n=14) \\
{[18]}\end{array}$ & $\begin{array}{c}100 \%(\mathrm{n}=2) \\
{[53]}\end{array}$ & $0.0 \%(n=7)[28]$ \\
\hline OCT1 & $61.5 \%(n=13)[59]$ & $62.5 \%(n=8)[12]$ & $\begin{array}{c}23.5 \%(n=17) \\
{[18]}\end{array}$ & No data & \\
\hline OCT2 & $61.5 \%(n=13)[59]$ & No data & $\begin{array}{c}23.5 \%(\mathrm{n}=17) \\
{[18]}\end{array}$ & No data & No data \\
\hline MATE1 & $23.1 \%(n=13)[59]$ & No data & $\begin{array}{c}14.3 \%(\mathrm{n}=14) \\
{[18]}\end{array}$ & No data & No data \\
\hline MATE2-K & $0 \%(n=13)[59]$ & No data & $\begin{array}{c}0 \%(n=14) \\
{[18]}\end{array}$ & o data & No data \\
\hline OATPs & $\begin{array}{c}15.4 \% \\
(\text { OATP1B } 1) \\
0.0 \% \\
(\text { OATP2B } 1) \\
(\mathrm{n}=13)[59]\end{array}$ & $\begin{array}{c}0.0 \% \text { (Total } \\
\text { OATP activity) } \\
(\mathrm{n}=8)[12]\end{array}$ & $\begin{array}{c}14.3 \% \\
\text { (OATP1B1), } \\
0.0 \% \\
(\text { OATP1B3) } \\
(\mathrm{n}=14)[18]\end{array}$ & No data & No data \\
\hline OAT1 & $0 \%(n=13)[59]$ & No data & $\begin{array}{l}0.0 \%(n=17) \\
{[18]}\end{array}$ & No data & No data \\
\hline OAT3 & $23.1 \%(n=13)[59]$ & No dat: & $\begin{array}{c}23.5 \%(n=17) \\
{[18]}\end{array}$ & No data & No data \\
\hline
\end{tabular}

${ }^{\mathrm{a}}$ Pesticide concentrations are usually set at $100-250 \mu \mathrm{M}$ 
Table 4: Pesticides substrates for drug transporters

\begin{tabular}{ccc}
\hline Transporter & Substrate & Not substrate \\
P-gp & $\begin{array}{c}\text { Paraquat [31], ivermectin [38, 39], } \\
\text { endosulfan (weak substrate) [17] } \\
\text { Methoxychlor [50], fenitrothion [50], } \\
\text { chlorpropham [50], ivermectin [38] }\end{array}$ & $\begin{array}{c}\text { Propiconazole [25], deltamethrin [41], cis- } \\
\text { permethrin [41], trans-permethrin [41], } \\
\text { warfarin [42], cyperquat/MPP+ [29] }\end{array}$ \\
\hline BCRP & Warfarin [54] & Ivermectin [55] \\
OCT1 & Cyperquat/MPP+ [60] & $\begin{array}{c}\text { Allethrin (present study), tetramethrin } \\
\text { (present study), paraquat [65], fenamiphos } \\
\text { [59], phosmet [59] }\end{array}$ \\
\hline OCT2 & Cyperquat/MPP+ [60], paraquat [65] & $\begin{array}{c}\text { Allethrin (present study), tetramethrin } \\
\text { (present study), fenamiphos [59], } \\
\text { phosmet [59] }\end{array}$ \\
\hline OCT3 & Cyperquat/MPP+ [61] & Paraquat [65] \\
\hline MATE1 & Cyperquat/MPP+ [62], paraquat [65] & No data \\
\hline OAT2-K & Cyperquat/MPP+ [63] & No data \\
\hline OAT3 & 2,4-dichlorophenoxyacetic acid \\
(2,4-D) [71] & No data \\
\hline
\end{tabular}

